\title{
Yeraltısuyu Çekimi Sonucu Oluşan Yüzey Çökmesi Problemi; Bilimsel Araştırmaların Tarihsel Gelişimi
}

\author{
Surface Subsidence Problem Due to Groundwater Withdrawal; A Historical Review \\ Nurkan KARAHANOĞLU D \\ Orta Doğu Teknik Üniversitesi Jeoloji Mühendisliği Bölümü, ANKARA
}

Geliş (Received): 12 Şubat (February) 2018, Düzeltme (Revised): 08 Mart (March) 2018, Kabul (Accepted): 20 Mart (March) 2018

\section{ÖZ}

Akiferlerden yoğun su çekimi sonucu oluşan yüzey çökmesi konusundaki bilimsel araştırmalar 1890'lı yıllara kadar uzanmaktadır. Zamanla teknolojik ve endüstriyel gelişmeler su ihtiyacını çok artırmış ve yeraltısuyu havzaları vazgeçilemez kaynak olarak kullanılmıştır. Sanayileşmenin yaygın olduğu bölgelerde gözlenen ve altyapıyı olumsuz olarak etkileyen bu gelişmenin yoğun su-petrol-gaz üretimi ile bağlantılı olduğu anlaşılmıştır. Daha sonraki yıllarda konunun bilimsel olarak araştırıldığı ve su/akışkan çekimi ile yüzeydeki deformasyonun ilişkilerinin matematiksel olarak ifade edildiği izlenmektedir. Yapılan araştırmalarda yeraltısuyu akımı ve deformasyon ilişkisi birlikte ele alınmış ve mekanizmaların fiziksel ve mekanik yanları incelenmiştir. Terzaghi'nin konsolidasyon modeli ve Biot'nun yeraltısuyu akımı ve yüzey deformasyonunu matematiksel olarak formüle etmesi araştırmalara çok önemli katkılar sağlamıştır. Bu gelişmeleri takip eden yıllarda ilgili mekanizmaları açıklayan matematiksel denklemlerin analitik yöntemlerle çözülmeleri önemli bir aşama olarak değerlendirilmiş, ancak karmaşık ve çok boyutlu ortamlarda analitik yöntemler yetersiz kalmıştır. Sonlu Farklar ve Sonlu Elemanlar sayısal yöntemlerinin kullanılması ve bilgisayar teknolojisindeki gelişmeler karmaşık problemlerin çözümünü sağlamış ve yapılan bilimsel araştırmalara ivme kazandırmıştır.

Bu makalede yüzey çökmesi konusundaki araştırmalar tarihsel boyutta özetlenerek konunun bilimsel gelişimi aktarılmaktadır. Temel denklemler yardımı ile su hareketi ve yüzey çökmesi mekanizması anlatılmakta ve dünya genelinde yüzey çökmesi yaşanan bölgeler tanıtılarak konu ile ilgili güncel araştırmalar irdelenmektedir.

Anahtar Kelimeler: Yüzey çökmesi, yeraltısuyu akımı-deformasyon ilişkisi, poroelastisite

\begin{abstract}
Scientific investigations for surface subsidence caused by groundwater date go back to 1890's. Technological and industrial developments have rapidly increased the demand for groundwater and this resulted heavily use of groundwater resources. This phenomenon, observed in industrial areas and causing damage to infrastructures, has been related to heavy production of water-oil-and gas. In the following years, research studies have been focused on mathematical formulation of the interrelated mechanism of fluid withdrawal and subsidence. In the formulation, mechanical and physical behaviour of the flow and subsidence mechanisms are used together to analyze their interrelationships. Research studies have been accelerated by Terzaghi's consolidation model and Biot's mathematical formulation of the phenomenon. In the following years, solution of the equations were tried by analytical methods, however, they were not applicable to complex problems. Use of the numerical methods (Finite
\end{abstract}


Karahanoğlu

Elements and Finite Differences) and high capacity computers have been applied to solve the problems and this has speeded up the research studies.

This paper summarizes the research studies related to subsidence due to fluid withdrawal and the scientific development has been reviewed. The mechanisms of subsidence and fluid flow have been explained and case examples are given from countries which seriously suffer from surface subsidence.

Keywords: Surface subsidence, deformation and fluid flow interrelation, poroelasticity

\section{GíRİş}

Yeraltısuyu çekimi, jeotermal akışkan ve petrol-gaz üretimi akifer-rezervuar sistemlerinde deformasyonlara neden olmakta ve bu durum bölgesel boyutta yüzey çökmesi, kırılmalar, çatlamalar şeklinde gözlenmektedir. Dünya geneline bakıldığında, 1900'lü yılların başından itibaren gözlenen yüzey çökmesi problemi, endüstriyel gelişmelere paralel olarak hızla artan yeraltısuyu kullanımı sonucu, çok ciddi boyutlarda hasar oluşturmaya başlamıştır. $\mathrm{Bu}$ durum, yüzey çökmesi yaşayan ülkelerin konuya gereken önemi vermesini sağlamış ve problemin tanımına, mekanizmasının anlaşılmasına ve çökmenin ve dolayısı ile dolaylı hasarların en az düzeye indirilmesini sağlamak için araştırma ve gözlemlerin yapılmasına vesile olmuştur. $\mathrm{Bu}$ konuda yapılan bilimsel araştırmaların odağını, problemin hidromekaniğini tanımlayan matematiksel modeller ve ilgili denklemlerin sayısal yöntemlerle çözülmesi ve oluşan hasarların minimize edilmesini hedefleyen çalışmalar oluşturmaktadır. $\mathrm{Bu}$ bağlamda çok sayıda bilimsel araştırma yapılmış ve geliştirilen sayısal modellerin uygulanmasıyla birçok bölgede yüzey çökmesi problemi kontrol altına alınmış ve hasarların minimize edilmesi yönünde sürdürülebilir mekanizmalar geliştirilmiştir.

$\mathrm{Bu}$ makalede yeraltısuyu çekimi ve petrolgaz-jeotermal üretimi sonucu oluşan yüzey çökmesi probleminin tanıtılması, bilimsel ve mühendislik boyutlarının aktarılması amaçlanmaktadır. Makalenin akıșı içerisinde konu hakkında yapılan araştırmaların tarihsel gelişimi anlatılmakta ve yüzey çökmesi yaşayan ülkelerden örnekler verilerek problemin önemi vurgulanmaktadır. Ayrıca problemin hidrodinamik ve mekanik boyutlarının sonlu elemanlar sayısal yöntemi ile modellenmesi konusunda temel bilgiler aktarılmaktadır.

\section{TARIHHSEL GELIȘIM}

Yüksek miktarda yeraltısuyu çekimi sonucu akiferlerde ve yüzeyde oluşan çökme mekanizması ile ilgili olarak yapılan gözlemler ve bilimsel araştırmalar 1890'l1 yıllara kadar uzanmaktadır. Meinzer, 1928 yılında yazdığ makalede basınçlı akiferlerde oluşan sıkışma ve akiferlerin elastik özelliklerinin ve bunların artezyen basıncı ile ilişkilerinin 1890 yıllardan itibaren araştırıldığını bildirmektedir (Meinzer, 1928). Meinzer, Hay'in 1890 yılında yaptığ sunumda artezyen kuyulardaki su akımının "kaya basıncı" sonucu oluştuğunu ve plastik artezyen akiferi örten kayaların su üzerindeki basıncın su akımını sağladığını ifade ettiğini aktarmaktadır (Hay, R., 1890; Meinzer, 1928). Diğer taraftan, Avustralya'da 1906 y1lında Gregory (Meinzer, 1928) Avustralya merkezinde bulunan kuyularda su akımını kısmi olarak kaya basıncına bağladığını anlatmaktadır. Artezyen akiferlerin sıkışabilirlikleri ve elastisiteleri, Veatch tarafından 1906 yılında değerlendirilmiş ve su 
yüklerinin değişmesinin nedenleri açıklanmıştır (Veatch, 1908; Meinzer, 1928). Fuller, 1908 y1lında basincin akiferleri örten malzeme tarafından sağlandığını ve bu durumun su akımı ile ilişkili olduğunu anlatmaktadır (Fuller, 1908). Meinzer, makalesinde akiferlerin sıkışabilirlikleri ve elastisiteleri ile ilgili olarak yapılan değişik testlerden bahsetmektedir. Pratt ve Johnson, 1926 yılında Gulf körfezinde Goose Creek petrol sahasinda petrol, su, gaz ve kum üretimi sonucu oluşan yüzey çökmesini sunmaktadır (Pratt ve Johnson, 1926; Pratt, 1927). Riley (1998), 1920'lerin ortalarında Meinzer ve Terzaghi'nin boşluk suyu basıncındaki değişimi ile doygun sedimanlarda meydana gelen deformasyon mekanizmasının temel kavramlarını formüle ettiklerini ifade etmektedir. Diğer taraftan, Terzaghi'nin 1923'de ileri sürdüğü etkin gerilim teorisi zemin oturma problemlerinin çözümüne önemli bir ivme kazandırmış ve zemin oturması problemi de zemin çökmesinin önemli nedeni olarak değerlendirilmiştir. Rappleye (1933), (Gambolati ve Teatini, 2015) ilk kez yeraltısuyu pompalaması nedeniyle oluşan yüzey çökmesinin kaydını Santa Clara (Kalifornia) vadisinde yapmıştır ve Ingerson (1941), Delano-TulareWasco (Kalifornia) bölgesinde 1902, 1930 ve 1940 yıllarında yapılan ölçüm haritalarını karşılaştırılarak bölgedeki yüzey çökmesini çalışmıştır. Jacob (1940) yaptığ 1 çalışmada, elastik artezyen akiferden su çekildiği zaman boşluk basıncının düştüğünü, bunun çekilen suyun genleşmesinden, akiferin sıkışmasından ve akiferin etrafında bulunan kil tabakalarının sıkışmasından olduğunu açıklamıştır. Tolman ve Poland (1940) ve (Riley, 1998) Amerika Santa Clara Vadisi'nde meydana gelen çökme mekanizmasını, basınçlı akiferde su yükünün azalması sonucu killerde bulunan suların kaçtığını ve killerin üstten gelen yük ile çöktüğü şeklinde açıklamıştır. Kaliforniya'da iki vadide gözlenen çökme hareketleri ile ilgili yapılan çalışmalarda, kuyu ekstensometre ve su seviye ölçüm değerleri kullanılmış ve akitard deşarjı çökme teorisi için temel oluşturacak gerilimbirim deformasyon diyagramları elde edilmiştir. $\mathrm{Bu}$ diyagramlar, yaklaşı düşey permeabilite ve akitardların elastik ve elastik olmayan sıkıştırılma katsayılarının tahmin edilmesinde kullanılmıştır.

1940’lı y1llara kadar yeraltısuyu çekimi sonucu oluşan yüzey çökmesi probleminin neden sonuç ilişkileri üzerinde çalışmalar yapılmış ve ilgili mekanizmanın fiziksel ve mekanik boyutları araştırılmıştır. İlk kez, 1941 yılında Maurice Biot yeraltısuyu çekimi sonucu oluşan yüzey çökmesi mekanizmasını üç boyutlu matematiksel denklemler kullanarak modellemiş ve böylelikle yüzey çökmesi problemi matematiksel olarak ifade edilmiştir (Biot, 1941). Günümüz araştırmacılarının çoğu tarafından yüzey çökmesi probleminin araştırılması alanında temel araştırma olarak kabul edilen bu çalışmada, genel gerilim ve birim deformasyon ilişkileri üç boyutlu denklemler kullanılarak yazılmakta ve bu denklemlere su basıncı değişkeni eklenerek çökme mekanizması ile su akımı birbirleri ile tam etkileşimli olarak ifade edilmektedir.

1950'li ve 1960'l1 yıllarda baz1 araştırmacıların (Poland, 1958, 1960, 1961; Poland ve Davis, 1956; Poland vd., 1959) yeraltısuyu çekimi ve yüzey çökmesi arasındaki bağlantı ile ilgili yaptıkları gözlemler ve araştırmalar konunun dünya genelinde kabul görmesini sağlamıştır. Bu yıllarda kaya mekaniği dalında etkin gerilim (efektif stres) kavramının yaygın kullanılmaya başlanması, yüzey çökmesi probleminin mekanizmasının tanımlanmasına çok önemli katk1 getirmiştir. Taylor (1948); Terzaghi ve Peck (1948) ve Mitchell (1962) etkin gerilim prensibi ve su basincindan elde edilen bilgilerin ince taneli toprak malzemenin 
davranışı ile çok ilişkili olduğunu söylemişlerdir. Bunlara ek olarak, Londra'da ve Meksiko şehrinde meydana gelen çökmelerden Domenico ve Mifflin (1965)'de yapılan çalışmasında bahsedilmekte ve efektif gerilmenin yeraltısuyu pompalanması sonucu yükselmesinin yüzeyde ölçülebilir seviyede deformasyonun (çökmenin) oluşmasına neden olduğu anlatılmaktadır.

1970'li y1llarda yeraltısuyu çekimi ile oluşan çökme mekanizmasının matematiksel modellenmesi ve ilgili denklemlerin çözülmesi yönünde yapılan araştırmalar yoğunluk kazanmıştır. Yokoo vd., (1971a, 1971b) makalelerinde stres analizinde uygulanan sonlu elemanlar yöntemini Biot'nun konsolidasyon teorisine uygulamışlar ve homojen olmayan, anizotropik ve elastik malzeme (bir, iki ve üç boyutlu) için sayısal çözüm yöntemi geliştirmişlerdir. Gambolati ve Freeze (1973) ve Gambolati vd. (1974) yayınladıkları makalelerde Venedik şehrinin çökmesi ile ilgili olarak matematiksel bir benzeşim çalışması sunmuşlardır. $\mathrm{Bu}$ araştırmalarda yeraltısuyu çekimi ile yüzey çökmesinin hesaplanabilmesi için yeraltısuyu hareketini kontrol eden akım denklemi ile konsolidasyon denkleminin birbirleri ile etkileşimli duruma getirilmesi gerektiğini söylemişlerdir. Çorapçığlu ve Brutsaert (1977), basınçlı akiferlerde yeraltısuyu çekilmesi sonucu boşluk basıncının azaldığı ve bunun sonucu olarak etkin gerilimin artmasıyla akiferde ve dolayısı ile yüzeyde deformasyon oluştuğunu ve çökme meydana geldiğini söylemişlerdir. Ayrıca deformasyonun elastik olmayıp visko-elastik davranış gösterdiğini ve dolayısı ile önerilen bu yaklaşımın birincil ve ikincil konsolidasyonu daha başarılı olarak modellediğini ifade etmişlerdir. Lewis ve Schrefler (1978) yeraltısuyu çekimi sonucu Venedik'te meydana gelen yüzey çökmesi problemini modellemek için tam etkileşimli bir sonlu elemanlar yöntemi geliştirmiş ve model sonuçlarının bölgedeki çökmeyi çok başarılı şekilde modellediklerini belirtmişlerdir. Lewis ve Karahanoğlu (1981) jeotermal sahalarda üretim sonucu oluşacak yüzey çökmesini modelleyen matematiksel denklemleri formüle etmişler ve bu denklemleri sonlu elemanlar yöntemini kullanarak çözmüşlerdir. Bear ve Çorapçığlu (1981a, 1981b) yaptıkları çalışmalarda yeraltısuyu çekimi sonucu oluşacak yüzey çökmesini düşey ve hem düşey hem yatay bileşenini dikkate alan formüller geliştirmişlerdir. Bear ve Çorapçıoğlu (1981c) sıcak su basımı ve çekimi sonucu termo-elastik akiferde oluşacak yüzey çökmesini matematiksel olarak modellemişlerdir. Çorapçığlu (1984) hazırladığ 1 makalede, yeraltısuyu çekimi sonucu oluşan yüzey çökmesi konusunda yapılan araştırmaları özetlemiştir. Karahanoğlu vd. (1984) sıcak su tipi jeotermal rezervuarlarda üretim sonucu oluşacak yüzey çökmesini matematiksel olarak ifade etmişler, sonlu elemanlar yöntemini kullanarak geliştirdikleri sayısal modeli Kızıldere sahasına uygulayarak ileriye yönelik sıcaklık, basınç ve deplasmanlar için tahminler yapmışlardır. Aboustit vd. (1985) varyasyonel prensibi ve sonlu elemanlar yöntemini kullanarak termo-elastik ortamdaki konsolidasyonu modellemişlerdir. Lewis vd. (1989) sonlu elemanlar yöntemini kullanarak, deforme olan gözenekli ortamda iki boyutlu 1sı ve iki fazlı akışkan akımını modellemişler ve zamana bağlı kısmi diferansiyel denklemleri deplasman, boşluk suyu basıncı ve sıcaklık değişkenleri için birbirleri ile tam etkileşimli olarak yazmışlardır. Gambolati vd. (1991) İtalya'nın Ravenna bölgesindeki yüzey çökmesinin (1950-1986 yılları arasında toplam $1.30 \mathrm{~m}$ ) yeraltısuyu çekimi sonucu akitardda ve rezervuarda oluşan kompaksiyon nedeniyle ve bölgedeki gaz kuyularından yapılan üretim sonucu olduğunu vurgulamaktadır. 
1990’11 y1llardan sonra yüzey çökmesi konusunda yapılan çalışmaların ve araştırmaların sayısında çok artış olmuştur. Araştırmaların büyük çoğunluğunu dünyanın değişik bölgelerinde meydana gelen yüzey çökmesi ve bu olayın yarattığı olumsuz etkileri çözmeye yönelik bilimsel çalışmalar oluşturmaktadır. Bunların yanında çökme probleminin hidrodinamik ve mekanik özelliklerinin de ayrıntılı olarak araştırıldığ 1 çalışmalar ve bu çerçevede kurulan sayısal modelleri bilimsel olarak geliştiren araştırmalar da bulunmaktadır. 2000'li yıllardan itibaren 3 boyutlu modeller geliştirilmiştir ve araştırmaların büyük bir kısmında yüzey çökmesinin hem yatay hem de düşey boyutta olacağı varsayımı dikkate alınmıştır.

Cheo vd. (1992) tabakalı zeminde yapilan yoğun yeraltısuyu çekiminin etkisini araştırmışlar ve boşluk suyu basıncının zemin çökmesi ile doğrusal olmayan şekilde bağlandiğını ve toplam gerilimin derinlik boyutundaki değişiminin uniform (tek düze) olmadığını açıklamışlardır. Yeh vd. (1996) akiferde basınç düşümü sonucu gelişen çökme mekanizmasını araştırmışlar, denge denklemlerini ve çok boyutlu akım denklemlerini tam etkileşimli olarak kullanmışlar ve Galerkin sonlu elemanlar yöntemini kullanarak elde ettikleri çözümleri analitik çözümlerle karşılaştırmışlardır.

Bunlara ek olarak Riley (1998), Dr. Poland'ın araştırmalarına atıf yaparak konunun gelişimi hakkında bilgiler vermiş ve ekstensometre/piyezometre ölçümleri üzerinde yaptıkları sayısal modelleme sonuçlarının değerlendirmelerinde elastik ve elastik olmayan sıkıştırma katsayılarının çok etkili olduğunu ve elastik olmayan depolamanın elastik depolamaya göre 20 - 100 kata kadar fazla olabileceği yorumunu yapmışlardır. Elastik olmayan depolama boşaltılmasının yenilenemeyen rezerv olarak değerlendirilmesi gerektiği ve kaçınılmaz olarak yüzey çökmesinin oluşacağı belirtilmiştir.

Shearer (1998) MODFLOW programinda yapılan değişiklik ile (Tabakalar Arası Drenaj Paketi) Çin'in Tianjin bölgesinde yeraltısuyu çekimi ile oluşan yüzey çökmesi problemini çalışmıştır. Bölgede konsolide olmamış Kuvaterner ve Neojen yaşlı denizel kum ve kil seviyelerinden oluşan 10 farklı akiferin bulunduğu, 1950 yılından beri yüzey çökmesi tespit edildiği ve bu çökmenin artan sanayi gelişmesi nedeniyle bölgede yapılan yoğun yeraltısuyu çekimi sonucu $88 \mathrm{~mm} / \mathrm{y} 1$ seviyesine kadar yükseldiği belirtilmektedir. Hazırlanan model uygun sınır koşulları ile uygulanmış, 1957 1993 yıllarına ait çökme verileri kullanılarak kalibre edilmiş ve farklı üretim senaryoları kullanılarak 2020 yılı için yüzey çökmesi tahminleri yapılmıştır.

Kim ve Parizek (1999) geliştirdikleri sayısal modelde poroelastik davranış varsayımı ile doygun olmayan gözenekli ortamdan su çekilmesi ile oluşan üç boyutlu konsolidasyon problemini Galerkin Sonlu elemanlar yöntemi ile araştırmışlardır.

Burbey ve Helm (1999) geliştirdikleri 3 boyutlu akım ve deformasyon modelinde MODFLOW programina GDM (taneli deformasyon modülü) eklemişlerdir. Yeraltısuyu çekimi ile oluşan çökmenin, killerin ve örtü tabakaların elastik olmayan birimleri içinde olduğunu ileri sürmüşlerdir. Yatay yönde olan deformasyonun ise taneli malzemelerde oluştuğunu söylemişlerdir.

Pei vd. (2000) tarafından üç boyutlu sayısal model geliştirilerek Çin'in Suzhou şehrinde meydana gelen yeraltısuyu çekimine bağlı yüzey çökmesi problemi modellenmiş ve yeraltısuyu akımı ve doğrusal olmayan konsolidasyon öngörülü model denklemleri sonlu farklar yöntemi ile çözülmüştür. 
Karahanoğlu

Gambolati vd. (2000), Po ovasındaki yüzey çökmesi problemini yeraltısuyu akım denklemi ile poroz ortam deformasyonu ilişkilerinin etkileşimli ve bağımsız olarak çözülmesini incelemişlerdir. Sonlu elemanlar yöntemi kullanılmış ve her iki durumda boşluk basıncı değişkeninin üretim formasyonunda etkilenmediği, üretim zonunun yanındaki akitard birimlerde ise etkileşimli çözümün yüksek basınç değerleri verdiği ve basıncın kısa bir zaman içinde ortam deformasyonuyla-yüzey çökmesi sonucu düştüğü belirtilmiştir. Genel değerlendirme olarak bağımsız çözüm yönteminin normal konsolidasyon ve basınçlı ortamlarda güvenilir sonuçlar verdiği ifade edilmiştir.

Gambolati vd. (2001), petrol ve gaz sahalarında oluşan yüzey çökmesinin tahmin edilmesi için poroelastik denklemlerin çözümünde "sanal iş" (virtual work) prensibini kullanarak ya taneler arası etkin gerilim ile boşluk basıncı gradyanı dağıtılmış kütle yükü olarak ya da, toplam gerilim boşluk basıncı ile birlikte değerlendirmişler ve oluşturulan denklemleri özetlemişler ve tartışmışlardır.

Li (2002), yeraltısuyu çekimi ve enjeksiyonu ile oluşan yüzey değişimini modellemiş ve parametrelerin duyarlılığını araştırmıştır. Li (2003), tek boyutlu yüzey çökmesi problemini analitik olarak incelemiş ve suya doygun akifer biriminin doğrusal olmayan yarı-poroz bir ortam olarak değerlendirildiğini ve Las Vegas'taki akiferde yapılan depolama ile su çekimi uygulamalarının yaratabileceği olası çökme problemlerinin araştırıldığını anlatmaktadır.

Kim (2004; 2005) doygun olmayan ve anizotropik ortamda yeraltısuyu çekimi ile oluşan üç boyutlu yeraltısuyu akımı ve yüzey deformasyonunu modellemek amaciyla hidrojeomekanik sayısal model geliştirmiştir. Doygun ve doygun olmayan ortamda ve deformasyona uğrayan anizotropik jeolojik ortamda yeraltısuyu akımını modellemek amacı ile tam etkileşimli poroelastik denklemler kullanılmış ve Galerkin sonlu elemanlar yöntemi uygulanmıştır. Sayısal benzeşim çalışmaları ile anizotropinin, hidrolik yük ve deplasman vektörlerinin zaman ve mekan boyutundaki dağılımlarına etkileri araştırılmıştır.

Shen vd. (2006), 3 boyutlu akım ve tek boyutlu (düşey) deformasyonu modellemişler ve Japonya' da gaz üretim sahasına uygulamışlardır.

Teatini vd. (2006), İtalya'da Po ovasındaki Emilia Romagna bölgesinde ekonomik ve turizm nedenleriyle yapılan yoğun yeraltısuyu çekimlerinin yüzey çökmelerine etkilerini araştırmışlar, sonlu elemanlar akım ve poromekanik deformasyon modeli kullanmışlar ve çalışmalarını ayrıntılı jeolojik çalışmalarla desteklemişlerdir. Geliştirilen model ile 1946 yılından itibaren olan gelişmeler değerlendirilmiş, son model 50 yıldır yapılan piezometre ve extensometre ölçümleri ile kalibre edilmiş ve 2016 yılı için yüzey çökmesi tahminleri yapılmıştır.

Kihm vd.(2007), 3 boyutlu model ile doygun olmayan nehir sedimanlarından oluşan akiferde su akımı ve çökme mekanizmasını tam etkileşimli olarak modellemişlerdir. Yapılan çalışmada önce durgun ortamda basınç yükleri, hidrolik yükler ve akım hızlarının dağılımı bulunmuş ve ikinci aşamada doygun olmayan zamana bağl1 durumda basınç yükleri, hidrolik yükler ve akım hızlarının hesaplandığı ve sonuçların sahada ölçülen hidrolik yükler ve düşey deplasman ile uyumlu olduğu belirtilmiştir.

Settari vd. (2008), Kuzey Adriyatik'te bulunan rezervuarda gaz üretiminin neden olduğu yüzey çökmesini çalışmışlardır. Araştırmada rezervuarın tanımlanmasının ve çökme mekanizmasının karmaşık olması rezervuar ve jeomekanik simülatörlerin etkileşimli olarak uygulanması gereğini ortaya çıkartmıştır. Tam 
etkileşim durumunda sonuçların sadece akifer alanı ile sinırlı olduğu bu nedenle doğrudan yapılan etkileşimle daha sağlıklı sonuçların alınabileceği vurgulanmıştır.

Kumarc1 vd. (2008), WTAQ programı kullanarak sonlu elemanlar yöntemi ile basınç düşümü sonunda oluşan çökmeyi hesaplamışlar ve modellerinde zamana bağlı elastik davranış kullanmışlardır.

Castelletto vd. (2008), araştırmalarında Venedik şehrinin kurtarılmasına yönelik olası projeleri tartışmışlardır. Enjeksiyon yapılarak şehrin yükseltilmesi projesi değerlendirilmekte ve bu konu ile ilgili olarak yapılması gerekli araştırmalar irdelenmektedir.

Wu vd. (2009), Çin'in Su-Xi-Chang bölgesinde meydana gelen yüzey çökmesi problemini çalışmışlardır. 3 boyutlu sonlu elemanlar modeli geliştirmişler ve konsolidasyon modellerinde hidrolik iletkenlik ve özgül depolama katsayılarının porozite ile değiştiği varsayımını kullanmışlardır. Oluşturulan model bölgeye uygulanmış ve 1996-2004 arası dönem için elde edilen sonuçların gözlenen değerlerle iyi bir uyum sağladığı ifade edilmiştir.

Shen ve Xu (2011), Shangay şehrinde meydana gelen yüzey çökmesi problemini üç boyutlu yeraltısuyu akımı ve tek boyutlu deformasyon koşulları altında çalışmışlar ve uygulamalarını Shanghay şehrinin çok tabakalı ve yumuşak akifer-akitard sisteminde yapmışlardır. Konsolidasyon ile etkilenen sıkıştırma katsayısı ve hidrolik iletkenlik özelliğini çalışmalarında kullanmışlar ve çekilen su miktarı, su çekilen seviye ve su çekilen bölgenin yüzey çökmesine etkisini irdelemişlerdir.

Ye vd. (2011), çok ölçekli sonlu elemanlar modeli ile bölgesel ve yerel çökmeleri ve Shanghay'da 1986-1988 arasında gözlenen yüzey çökmesini araştırmışlar ve Merchant modelinin değiştirilerek elastik, viskoelastik ve elastik-plastik parametreler kullanılarak modellenebileceğini anlatmışlardır.

Galloway ve Burbey (2011), yeraltısuyu çekimi ile oluşan yüzey çökmesi konusunda yapılan araştırmaları özetlemişlerdir. Söz konusu mekanizma ile oluşan yüzey hareketleri konusunda değişik bölgelerde yapılan gözlemler ve ilgili ölçme teknikleri anlatılmakta ve çökme hareketinin önlenmesi konusunda yapılan öneriler değerlendirilmektedir. Çökme hareketinin gözlenmesi için kullanılan ve uygulanan yöntemler (GPS, Extensometre, InSAR, LIDAR) hakkında bilgiler verilmektedir. Diğer taraftan bölgesel olarak gelişen yüzey çökmesinde akiferde gelişen düşey çökme hareketinin yanında, akitard içinde oluşan çökme hareketlerinin de etkili olduğu ve bu konuda yapılan modelleme çalışmaları hakkında bilgiler verilmekte ve olayın mekanizması detaylı bir şekilde aktarılmaktadır. Ayrıca MODFLOW programı ile bağlantılı yüzey çökmesi sayısal modelleri SUB, SUB-WT ve COMPAC ile ilgili simülasyon özellikleri karşılaştırmalı olarak özetlenmektedir.

Xu vd. (2012), üç boyutlu akımı ve buna bağlı tek boyutlu konsolidasyon sayısal modeli çalışmalarında Shanghay'da bulunan çok tabakalı akifer ve akitard sisteminde meydana gelen sızma ve yüzey çökmesi olgularını çalışmışlardır. İki senaryo şeklinde yapılan çalışmada, ilk olarak yeraltı yapılarının dağınık durumda olması ve ikinci senaryoda ise yeraltı yapılarının kentleşmenin yoğun olduğu bölgelerde bulunması değerlendirilmiş, değişik koşullar için yüzey çökmelerinde oluşacak artışlar tahmin edilmiştir.

Galloway ve Sneed (2013), ABD Jeoloji grubu tarafından yapılan üretime bağlı akifer kompaksiyonuveçökmesiproblemininçözümüne yönelik araştırmaları özetlemektedirler. Bunu 
Karahanoğlu

yaparken etkilenen akifer sistemini tanımlamayı, bölgesel değerlendirmeleri, mekanizmayı kontrol eden etkileşimli prosesleri analiz etmeyi geçmiş ve gelecekteki akım ve çökme mekanizmalarının davranışlarını göz önüne almayı hedeflemişlerdir.

Li vd. (2014), çalışmalarında, poroelastik iki boyutlu dikdörtgen ortamda zamana bağlı akım ve deformasyon denklemleri için analitik çözüm geliştirmişlerdir. İzotropik, homojen ve sıkışabilen poroz ortamda akışkan ve katı ilişkisi Biot'nun konsolidasyon modeli ile tanımlanmıştır. Analitik çözüm sonuçları tam çözümle ve sayısal çözümlerle karşılaştırılarak desteklenmiştir. Ayrıca basınçlı akiferden yapılan su çekimi örneği kullanılarak analitik çözüm değerleri ile sayısal çözümler arasındaki uyum geliştirilen analitik modelin hassasiyeti ve güvenilirliği için başarı ölçütü olarak ileri sürülmüştür.

Chang vd. (2014), tarafindan basit bir analitik model önerilmiş ve zamana bağlı yüzey çökmesi ile rezervuarın terk edilmesinden sonra şeyl içeren birimlerde oluşan çökme mekanizması poroelastik ve viskoelastik ilişki ile modellenmiştir.

Schmid vd. (2014), geliştirdikleri modelde, yüzey deformasyonunun akifer transmisivitesi ve depolaması ile etkileşimli olduğunu ve yüzey çökmesi ve yükselmesinin deformasyon bağımlı akımlarla ilişkilendirildiğini ve ayrıca akifer yüklerine ve diğer akım terimlerine bağlı olduğunu ileri sürmüşlerdir.

Zhang vd. (2015), Shanghay'da yeraltısuyu çekimi ve suyun geri basımı sonucu gelişen yüzey çökmesi ve yüzey yükselmesi mekanizmalarını arazi ve laboratuvar değerlerini kullanarak çalışmışlardır. Uzun dönemli yeraltısuyu çekilmesi sonucu akifer ve akitard seviyelerde oluşan deformasyonun elastik, plastik, visko elastik ve viskoplastik bileşenlerinin olduğu, geri kazanılabilen elastik ve viskoelastik deformasyonların toplam deformasyonun çok küçük bir parçası olduğu belirtilmektedir. Ayrıca yüzey çökmesinde ve yükselmedeki gecikmenin (yeraltısuyu seviyesindeki yükselmeye göre) tüm birimlerdeki visko-plastik deformasyona ve akitard seviyelerdeki konsolidasyona bağlı olduğu belirtilmektedir.

Gambolati ve Teatini (2015), yeraltısuyu çekimi/enjeksiyonu sonucu oluşan yüzey çökmesi/yüzey yükselimi, yüzeyde oluşan kırıklar, dolaylı olarak gelişen sismik aktiviteler konularını değerlendirmekte ve konu ile ilgili tarihsel gelişimi dünyanın değişik bölgelerinden örneklerle aktarmaktadır. Ayrıca yüzey çökmesi ve yüzey yükselmesi konularındaki mekanik prosesler ayrıntılı olarak anlatılmakta ve bu konulardaki etkileşimli diferansiyel denklemler verilmektedir. Yeraltısuyu çekimi ve enjeksiyonu ile oluşan yüzey deformasyonlarının mekanik özellikleri ve ilgili denklemler bu araştırmada ayrıntılı olarak anlatılmaktadır. Ayrıca yüzey deformasyonlarının gözlenmesi ve ölçülmesi konusundaki uygulamalar hakkında bilgiler verilmektedir.

Lin vd. (2015), Pekin'in kuzey bölgesinde 2003-2010 yılları arasında meydana gelen yüzey çökmesinin nedenlerini araştırmayı, bu olayın gelişmesini tanımlamayı ve tetikleyici faktörleri belirlemeyi amaçlamışlardır. $\mathrm{Bu}$ amaçla kuyu ekstensometre verileri, interferometri'den elde edilen yüzey çökmeleri, yeraltı su seviyeleri, hidrojeolojik bilgiler ve Landsat TM görüntülerini kullanılarak yüzey çökmesinin mekansal ve zaman boyutundaki yapıları araştırılmış, yüzey çökmesinin yeraltısuyu seviye değişimleriyle, sıkıştırılabilen tabaka kalınlığ 1 ve şehirleşme ile olan ilişkileri incelenmiş ve yüzey çökmesinin derinlik boyutundaki dağılımı için siltli kil seviyelerinin yüzey çökmesinde etkili olduğu vurgulanmıştır. 
Lin vd. (2015), çok tabakalı akifer sisteminde yeraltısuyuakımınıvedeformasyonumodellemek için 3 boyutlu analitik benzeri yeraltısuyu akım modeli ve tek boyutlu deformasyon modeli önermişlerdir. Önerilen model yardımı ile analitik çözüm ile su seviyelerinin bir kuyu etrafındaki değişimi modellenebilmekte ve tabakalardaki kompaksiyon hesaplanabilmekte ve kurulan modelin çoklu kuyu ve çok tabakalı sistemlerde kullanılabileceği belirtilmektedir.

Lei vd. (2015), hazırladıkları makalede, TOUGH 2 simülatörünü geliştirerek 3 boyutlu konsolidasyonu entegre etmişlerdir. Biot'nun 3 boyutlu konsolidasyon modeli TOUGH 2 deki çözüm sistemine bağlanmakta ve bu modelden elde edilen basınç ve sıcaklık değerleri ile permeabilitede ve porozitede meydana gelen değişiklikler TOUGH2 sisteminde tekrar çözümde kullanılmaktadır. Geliştirilen modelleme yöntemi tek boyutlu Terzaghi problemine, Çin'de bulunan bir $\mathrm{CO} 2$ projesine ve Kaliforniya' daki Gayzer sahasına uygulanmıştır.

Tsai (2015), tek boyutlu viskoelastikplastik konsolidasyon davranışını kullanarak komşu akiferlerdeki su yükü değişimine göre akitard konsolidasyonunu modellemektedir. Model değişken toplam gerilim yaklaşımını kullanmakta ve hidrolik yük ve düşey boyutta oluşacak deplasmanı tam etkileşimli şekilde çözmektedir. Çalışmada Voigt modeli kullanarak viskoelastik-plastik davranış şekli değişken yay elastik modülleri yardımı ile tanımlanmıştır. Ayrıca modelde yapılan hesaplamalar değişken hidrolik kondüktivite, elastik modül ve değişik kütle kuvveti kullanılarak yapılmıştır.

Kang ve Li (2015), çalışmalarında, MODFLOW-NDIS paketini geliştirmişler ve 3 boyutlu doğrusal olmayan deformasyon ve 3 boyutlu su akımı denklemlerini kullanmışlardır. Geliştirdikleri paketin MODFLOW-SUB paketine göre (tek boyutlu deformasyon) daha yeni ve gerçekçi olduğunu ileri sürmüşlerdir.

Yang vd. (2015), doğrusal olmayan hidrolik parametrelerin yeraltısuyu çekimi sonucu oluşan çökme hareketine etkilerini geliştirdikleri Galerkin Sonlu Elemanlar Modeli ile çalışmışlardır. Pompalama sonucu su seviyesinde oluşan düşümün basınç azalımına neden olduğu ve bunun porozite ve permeabiliteyi azalttığ 1 ve azalan permeabilitenin kuyuya yakın yerlerde hidrolik gradyanı ve sızma kuvvetlerini artırarak çökmeyi hızlandırdığı anlatılmaktadır.

Jafari vd. (2016), Terzaghi'nin tek boyutlu konsolidasyon teorisi ile 3 boyutlu yeraltısuyu akım modelini MOD-FLOW programına entegre etmişler ve İran'da Saveh sahasına uygulamışlardır. Model çalışmaları sonunda InSAR, extensometre ve sayisal model sonuçlarının birbirleri ile uyumlu olduklarını ifade etmişlerdir.

Ye vd. (2016a), Çin Shanghai bölgesinde oluşan yüzey çökmesini modellemek için birbirleri ile etkileşimli 3 boyutlu yeraltısuyu akımı ve 3 boyutlu akifer-sistem deplasmanı yaklaşımını kullanmışlar ve 1979-1995 yılları arasındaki durumu simüle etmişlerdir. Model kalibrasyonunda piyezometrik, jeodetik ölçümler ve kuyu extensometre değerleri 16 yıllık süre için kullanılmış ve 3 boyutlu model ile ölçülen piyezometrik ve deformasyon değerlerini başarılı olarak modellemiştir. Yatay deformasyonlar için ilk kez tahminler yapılmış ve bunların toplam yüzey çökmesinin \% 10' unu geçmeyeceği ve dolayısı ile yapılara (metro) zarar vermeyeceği ifade edilmiştir.

Zang vd. (2017), zemin iskelet yapısının dengesi ve yeraltısuyu akımının devamlılığ ilkelerini kullanarak tamamen etkileşimli üç boyutlu bir matematiksel model geliştirmiş ve modelde kullanılan mekanik ve hidrolik 
Karahanoğlu

parametreleri doğrusal olmayan ilişki ile tanımlamıştır.

\section{ÜLKELERDEN ÖRNEKLER}

Önceki kısımda yeraltısuyu çekimi sonrası oluşan yüzey çökmesi probleminin mekanizması ve modellenmesi konusunda yapılan çok sayıda makale özetlenmiş ve konu hakkında tarihsel gelişmeler bilimsel çerçevede sunulmuştur. $\mathrm{Bu}$ kısımda dünya genelinde ciddi boyutlara ulaşan ve şehirlerin altyapısını olumsuz olarak etkileyen ve ciddi çevre problemlerine neden olan yüzey çökmesinin ülkeler bazında değerlendirilmesi yapılmaktadır. Gambolati ve Teatini (2015) yaptıkları araştırmada, dünya genelindeki çökme probleminin dağılımını harita üzerinde göstermektedir (Şekil 1). İlgili ülkelerde gözlenen ve ayrıntılı olarak araştırılan problemin sayısal değerleri Çizelge 1'de verilmektedir. Çizelge dikkatli incelendiğinde 2015 y1lına kadar yapılan jeotermal akışkan üretimi sonunda Yeni Zelanda'nın Wairakei sahasında 14.5 m yüzey çökmesine neden olduğu anlaşılmaktadır. Ayrıca benzer bir şekilde Meksiko şehrinde yapılan yoğun su çekimi sonucu 13 m yüzey çökmesi meydana gelmiştir. Bu değerlerin yanında yüzey çökmesi probleminin görüldüğü alanın boyutları daha ürkütücüdür. ABD San Joaquin vadisinde etkilenen alanın $13500 \mathrm{~km}^{2}$ ve Houston'da ise $12000 \mathrm{~km}^{2}$ olduğu görülmektedir. Benzer örneklerin verildiğ i Çizelge 2'de Çin' de meydana gelen yüzey çökmeleri listelenmekte ve Çin'in Hebei bölgesinde 10 şehrin yüzey çökmesinden etkilendiği ve etkilenen alan toplamının 36000 $\mathrm{km}^{2}$ olduğu belirtilmektedir.

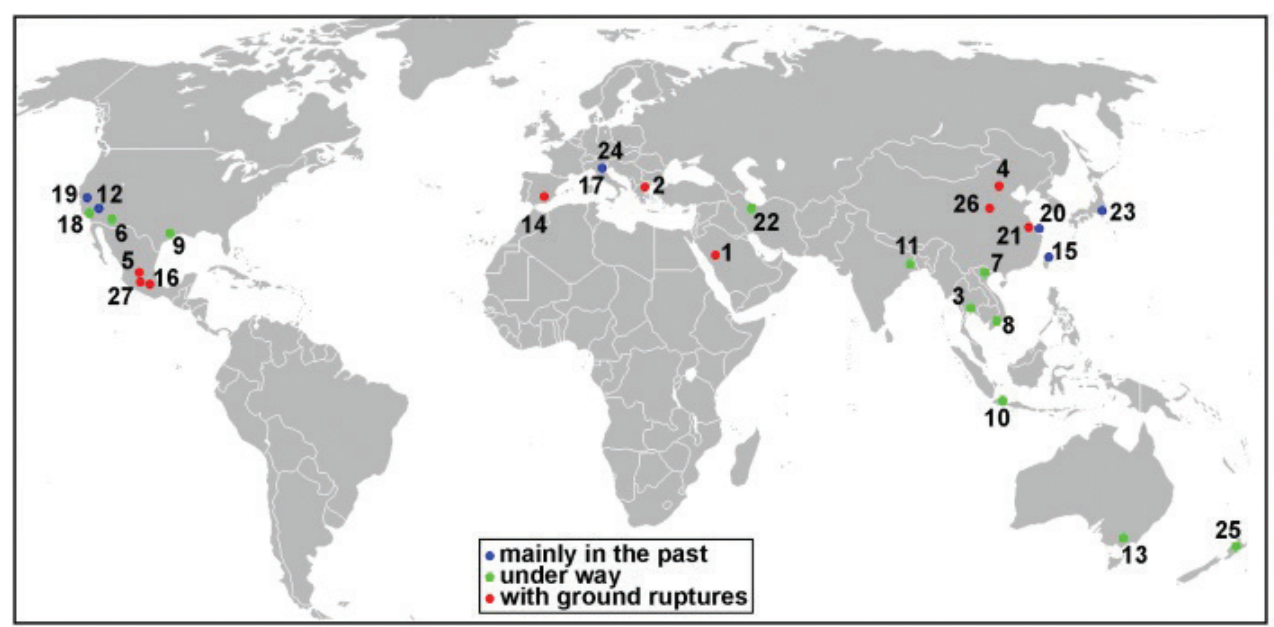

1: Wadi Al-Yutamah, Suudi Arabistan; 2: Anthemountas Baseni, Yunanistan; 3: Bangkok, Thayland; 4: Pekin, Çin Halk Cumhuriyeti; 5: Celaya, Mexico; 6: Eloy Baseni, Arizona; 7: Hanoi, Vietnam; 8: Ho Chi Minh, Vietnam; 9: Houston, Texas; 10: Jakarta, Indonezya; 11: Kolkata, Hindistan; 12: Las Vegas, Nevada: 13: Latrobe Vadisi, Avustralya; 14: Lorca, İspanya; 15: Taipei, Tayvan; 16: Mexico City, Mexico; 17: Ravenna, Italya; 18: San Joaquin Vadisi, Kalifornia; 19: Santa Clara Vadisi, Kalifornia; 20: Shanghai, Çin Halk Cumhuriyeti; 21: Su-Xi-Chang alanı, Çin Halk Cumhuriyeti; 22: Tehran, Iran; 23: Tokyo, Japonya; 24: Venedik, Italya; 25: Wairakei, Yeni Zelanda; 26: Xian, Çin Halk Cumhuriyeti; 27: Zamora de Hidalgo, Mexico Şehri.

Şekil 1. Dünya genelinde yeraltısuyu çekimi sonucu oluşan yüzey çökmesinin dağılımı (Gambolati ve Teatini, 2015). Haritada üç değişik tanım kullanılmıştır; i- geçmişte oluşanlar (mavi renkli noktalar), ii- halen devam edenler (yeşil renkli noktalar), iii- yüzeydeki çatlak oluşumları (kırmızı renkli noktalar).

Figure 1. Distribution of surface subsidence problems throughout the World (Gambolati and Teatini, 2015). Three different symbols are used in the map; i-mainly in the past; ii- under way; iii- with ground ruptures. 
Çizelge 1. Dünya'nın değişik bölgelerinde saptanan yüzey çökmesi (Gambolati ve Teatini, 2015).

Table 1. Surface subsidence detected in the World (Gambolati and Teatini, 2015).

\begin{tabular}{|c|c|c|c|c|}
\hline No & Bölge & Maksimum Çökme (m) & Derinlik (m) & Alan $\left(\mathbf{k m}^{2}\right)$ \\
\hline 1 & Wadi Al-Yutamah & $0.3(1993-1996)$ & $0-150$ & 150 \\
\hline 2 & Anthemountas Baseni & & $0-150$ & 40 \\
\hline 3 & Bangkok & 2.1(1933-2002) & $30-300$ & 700 \\
\hline 4 & Pekin & $1.1(1955-2007)$ & $20-400$ & 4200 \\
\hline 5 & Celaya & $3.1(1985-2008)$ & $50-200$ & 50 \\
\hline 6 & Eloy Baseni & $3(1948-1977)$ & $100-760$ & 1000 \\
\hline 7 & Hanoi & $0.5(1988-2003)$ & $0-80$ & 35 \\
\hline 8 & Ho Chi Minh & $0.4(1996-2005)$ & $50-240$ & 250 \\
\hline 9 & Houston & $3(1915-2000)$ & $60-900$ & 12000 \\
\hline 10 & Jakarta & $4.1(1974-2010)$ & $40-240$ & 660 \\
\hline 11 & Kolkata & $1.1(1956-2000)$ & $50-160$ & 150 \\
\hline 12 & Las Vegas & $2(1935-2000)$ & $200-300$ & 250 \\
\hline 13 & Latrobe Vadisi & $1.3(1960-1977)$ & $0-150$ & 400 \\
\hline 14 & Lorca & $2.2(1992-2012)$ & $50-300$ & 140 \\
\hline 15 & Taipei & $2(1955-1991)$ & $50-250$ & 200 \\
\hline 16 & Meksiko Şehri & $13(1960-2015)$ & $0-350$ & 250 \\
\hline 17 & Ravenna & $1.4(1897-2002)$ & $80-450$ & 400 \\
\hline 18 & San joaquin Vadisi & $10(1930-2015)$ & $60-600$ & 13500 \\
\hline 19 & Santa Clara Vadisi & $4.3(1910-1995)$ & $50-280$ & 500 \\
\hline 20 & Sanghai & $2.6(1958-2002)$ & $10-330$ & 5000 \\
\hline 21 & Su-Xi-Chang alanı & $1.1(1960-1995)$ & $20-200$ & 4000 \\
\hline 22 & Tahran & 3 (1989-2004) & $20-100$ & 500 \\
\hline 23 & Tokyo & $4.3(1900-1976)$ & $0-400$ & 3400 \\
\hline 24 & Venedik & $0.12(1952-1973)$ & $70-350$ & 150 \\
\hline 25 & Wairakei & $14.5(1950-2015)$ & $250-800$ & 25 \\
\hline 26 & Xian & $2.3(1959-1995)$ & $50-370$ & 240 \\
\hline 27 & Zamora de Hidalgo & & $0-300$ & 15 \\
\hline
\end{tabular}

Şekil 2, 3 ve 4 yüzey çökmesi probleminin evrensel boyutlarını ve çevresel etkilerini vurgulaması yönünden çarpıc1 örnekler göstermektedir. Bu şekillerde sunulan görseller, yeraltısuyu çekimi ile oluşan yüzey çökmesinin ciddi hasarlar oluşturabileceğini göstermesi açısından son derece etkileyicidir. 
Karahanoğlu

Çizelge 2. Çin'in önemli şehirlerinde gözlenen yüzey çökmesinin özeti (Hu vd. 2004'den Türkçe'ye çevrilmiştir). Table 2. Summary of surface subsidence observed in Major cities of China (translated from Hu et al., 2004).

\begin{tabular}{|c|c|c|}
\hline Şehir & $\begin{array}{l}\text { Alan } \\
\left(\mathbf{k m}^{2}\right)\end{array}$ & Açıklama \\
\hline Shangay & 850 & $\begin{array}{l}1920 \text { de başlayan çökme hareketi maksimum değere }(2.63 \mathrm{~m}) 1964 \text { yllında } \\
\text { ulaşmıştır. Çökme hareketi tedrici olarak kontrol altına alınmıştır. }\end{array}$ \\
\hline Tianjin & 10,000 & $\begin{array}{l}\text { 1959' dan beri ovada çökme hareketi olmakta ve } 10000 \mathrm{~km}^{2} \text { alanda etkisini } \\
\text { sürdürmektedir. Maksimum çökme } 3.06 \text { m dir ve ortalama çökme hızı } 8 \text { ile } 56 \mathrm{~mm} / \\
\text { yıl mertebesindedir. }\end{array}$ \\
\hline $\begin{array}{l}\text { Suzhou, Wuxi, } \\
\text { Changzhou }\end{array}$ & 380 & $\begin{array}{l}\text { Yüzey çökmesi } 1960 \text { dan itibaren gözlenmektedir ve kümülatif çökme değerleri } \\
\text { yaklaşı } 1 \mathrm{~m} \text { dolayında olup, çökme hızı } 15-50 \mathrm{~mm} / \mathrm{y} \text { ıl seviyesindedir. }\end{array}$ \\
\hline Ningbo, Jiaxing & 263 & $\begin{array}{l}\text { 1960-1989'a kadar bu şehirlerde kümülatif çökmeler } 0.346 \text { ve } 0.597 \text { m dolayındadır } \\
\text { ve çökme hızları } 18 \text { ve } 41.9 \mathrm{~mm} / \mathrm{y} 1 \mathrm{l} \text { dır. }\end{array}$ \\
\hline $\begin{array}{l}\text { Heze, Jining, } \\
\text { Dezhou }\end{array}$ & 53 & $\begin{array}{l}\text { Bu şehirlerde çökme } 1978 \text { yılında gözlenmiştir ve kümülatif değerler } 0.07,0.063 \\
\text { ve } 0.104 \text { m kadardır. Maksimum hızlar ise } 9.68,31.5 \text { and } 20 \mathrm{~mm} / \mathrm{y} 1 \mathrm{l} \text { dır. }\end{array}$ \\
\hline Xi’an & 250 & $\begin{array}{l}\text { 1950'lerde başlayan çökme maksimum } 1.9 \text { m ve maksimum çökme hızı yılda } 136 \\
\text { mm dir. }\end{array}$ \\
\hline $\begin{array}{l}\text { Xuchang, Kaifeng, } \\
\text { Luoyang, An'yang }\end{array}$ & 59 & $\begin{array}{l}\text { Çökme ilgili şehirlerde } 1985,1979 \text { ve } 1979 \text { yıllarında başlamıştır ve maksimum } \\
\text { çökme değerleri } 0.208,0.21,0.113 \text { ve } 0.337 \text { m olup; An'yang bölgesinde çökme } \\
\text { hızı yılda } 65 \text { mm dir. }\end{array}$ \\
\hline $\begin{array}{l}\text { Hebei Bölgesinde } \\
10 \text { şehir }\end{array}$ & 36,000 & $\begin{array}{l}\text { Bölgede çökme } 1950 \text { 'de başlamıştır. Etkilenen şehirler Cangtzhou, Hengshui, } \\
\text { Renqiu, Hejian, Bazhou, Baoding, Dacheng, Nangong, Feixiang, Handan'dır. } \\
\text { Maksimum çökme } 1.131 \mathrm{~m} \text { olup maksimum hız } 96.8 \mathrm{~mm} / \mathrm{y} \text { ıl dır. }\end{array}$ \\
\hline Fuyang & 360 & $\begin{array}{l}\text { Çökme } 1970 \text { yılında başlamıştır. Maksimum çökme } 1992 \text { de } 1.02 \mathrm{~m} \text { dir ve hız ise } \\
\text { yılda } 60-110 \mathrm{~mm} \text { arasındadır.. }\end{array}$ \\
\hline $\begin{array}{l}\text { Ha'erbing, Daqing, } \\
\text { Qiqiha'er, Jiamusi }\end{array}$ & $?$ & $\begin{array}{l}\text { Binalarda ve yüzeyde kırılmalar } 1974 \text { de başlamıştır ve nedeni tamamen yoğun } \\
\text { yeraltısuyu çekimidir. Ha'erbing ve Daqing bölgelerinde etkilenen alanlar } 258 \text { ve } \\
4000 \mathrm{~km}^{2} \text { dir ve yeraltısuyu çekilmeleri yılda } 26.85 \text { ve } 20-30 \text { m dolayındadır. }\end{array}$ \\
\hline $\begin{array}{l}\text { Taiyuan, Datong, } \\
\text { Yu'ci, Jiexiu }\end{array}$ & 200 & $\begin{array}{l}\text { Çökme Taiyuan'da } 1979 \text { yılında ve Datong'de } 1988 \text { 'de başlamıştır. Taiyuan'de } \\
\text { maksimum çökme } 1.967 \mathrm{~m} \text { ve hız yılda } 0.037-0.114 \mathrm{~mm} \text { dir. Datong, Yu'ci ve } \\
\text { Jiexiu şehirlerinde çökme hızları 31, 10-20 and } 5-7.5 \mathrm{~mm} / \mathrm{y} 1 \mathrm{l} \text { dır. }\end{array}$ \\
\hline Beijing & 314 & Çökme 1950 lerde başlamıştır ve maksimum kümülatif çökme 0.597 m dir. \\
\hline Kunming & $?$ & $\begin{array}{l}\text { Bu şehirde çökme doğu tren yolunda gözlenmiştir, ölçüm olmadığ için çökme } \\
\text { miktarı bilinmemektedir. }\end{array}$ \\
\hline Zhanjiang & 0.25 & $\begin{array}{l}\text { Çökme } 1960 \text { 'larda başlamıştır ve maksimum çökme } 0.11 \mathrm{~m} \text { olarak ölçülmüştür. } \\
\text { Çökme, su çekiminin azaltılması ile kontrol altına alınmıştır. }\end{array}$ \\
\hline Haikou & $?$ & 1990’larda 0.07 m olan çökme, son zamanlarda çok düşük seviyelerdedir.. \\
\hline Fuzhou & 9 & $\begin{array}{l}\text { Çökme } 1957 \text { yılında gözlenmiştir; kümülatif çökme } 0.68 \mathrm{~m} \text { dir ve çökme hızı ise } \\
\text { yılda } 2.9-21.8 \mathrm{~mm} \text { arasındadır. }\end{array}$ \\
\hline ÖZET & 48,728 & $\begin{array}{l}\text { Çin'de } 39 \text { şehir yüzey çökmesinden etkilenmiştir. Bu şehirler Yangtze nehri deltas } 1 \\
\text { ovasında, Hebei ovasında, Kuzeydoğu Çinde, Huanghe nehri ovasında ve dağlık } \\
\text { bölgedeki ovalarda yer almaktadır. Yüzey çökmesi probleminden dolayı toplam } \\
\text { ekonomik kayıp } 1997 \text { yılı itibarı ile RMB } \$ 100 \text { milyon dur. }\end{array}$ \\
\hline
\end{tabular}




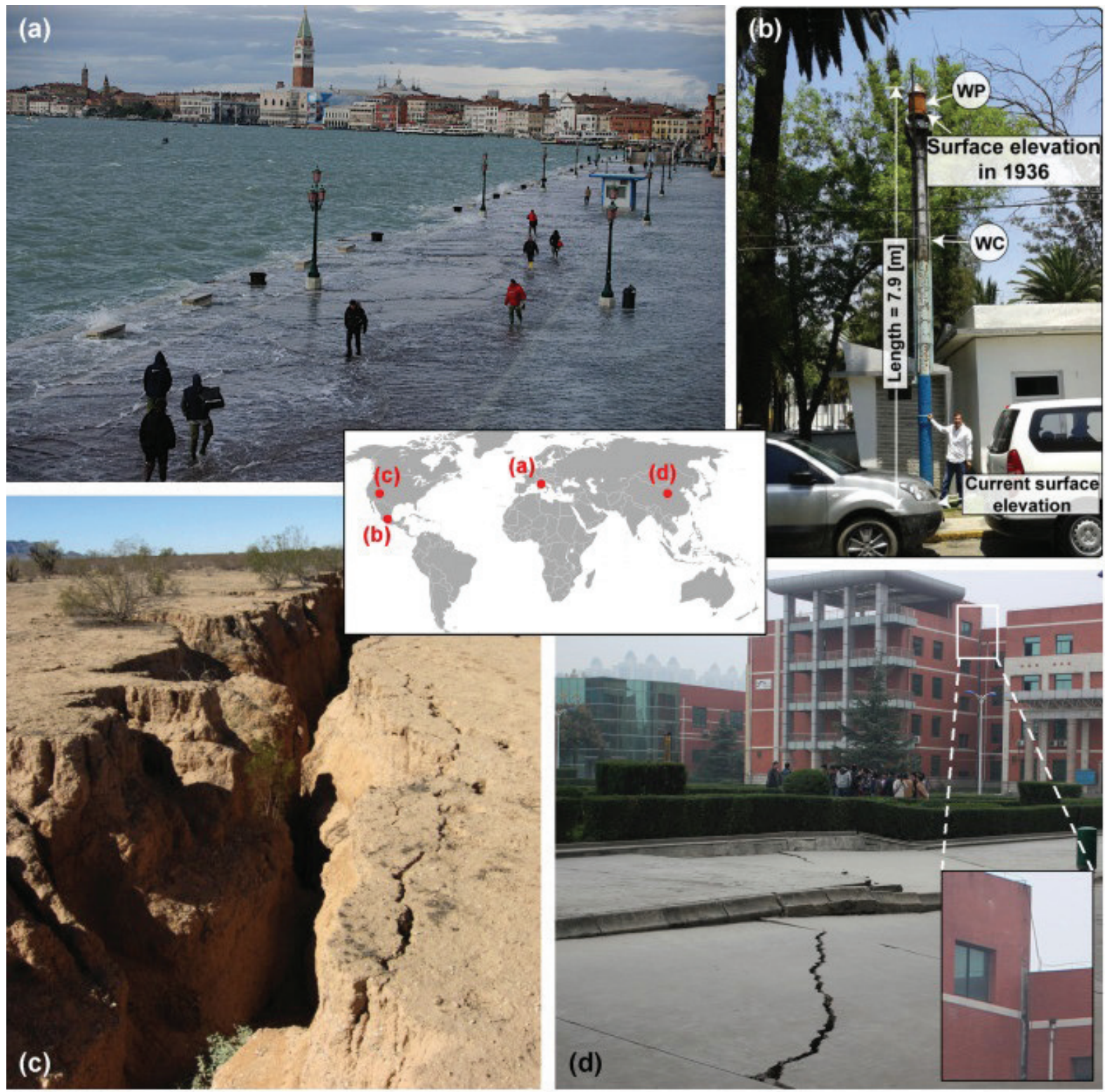

Şekil 2. Yüzey çökmesi ile ilgili bazı görseller a) Venedik’te 2013 de gel-git zamanı oluşan su basması, b) Meksiko şehrinde bulunan bir kuyuda yapılan ölçüm 1936-2003 yılları arasındaki yüzey çökmesini göstermektedir, c) Arizona Maricopa'da oluşan 13 m derinlikteki yüzey yarığı, d) Çin'de Xian şehrinde caddede oluşan çatlak ve binadaki hasar (Gambolati ve Teatini, 2015).

Figure 2. Some examples for surface subsidence: a) tidal flood in Venice in 2013, b) subsidence measured during 1936-2003 in a well in Mexico, c) surface rupture, $13 \mathrm{~m}$ deep, in Maricopa, Arizona, d) crack formed on the street and deviation in a building in Xian City, China (Gambolati and Teatini, 2015). 


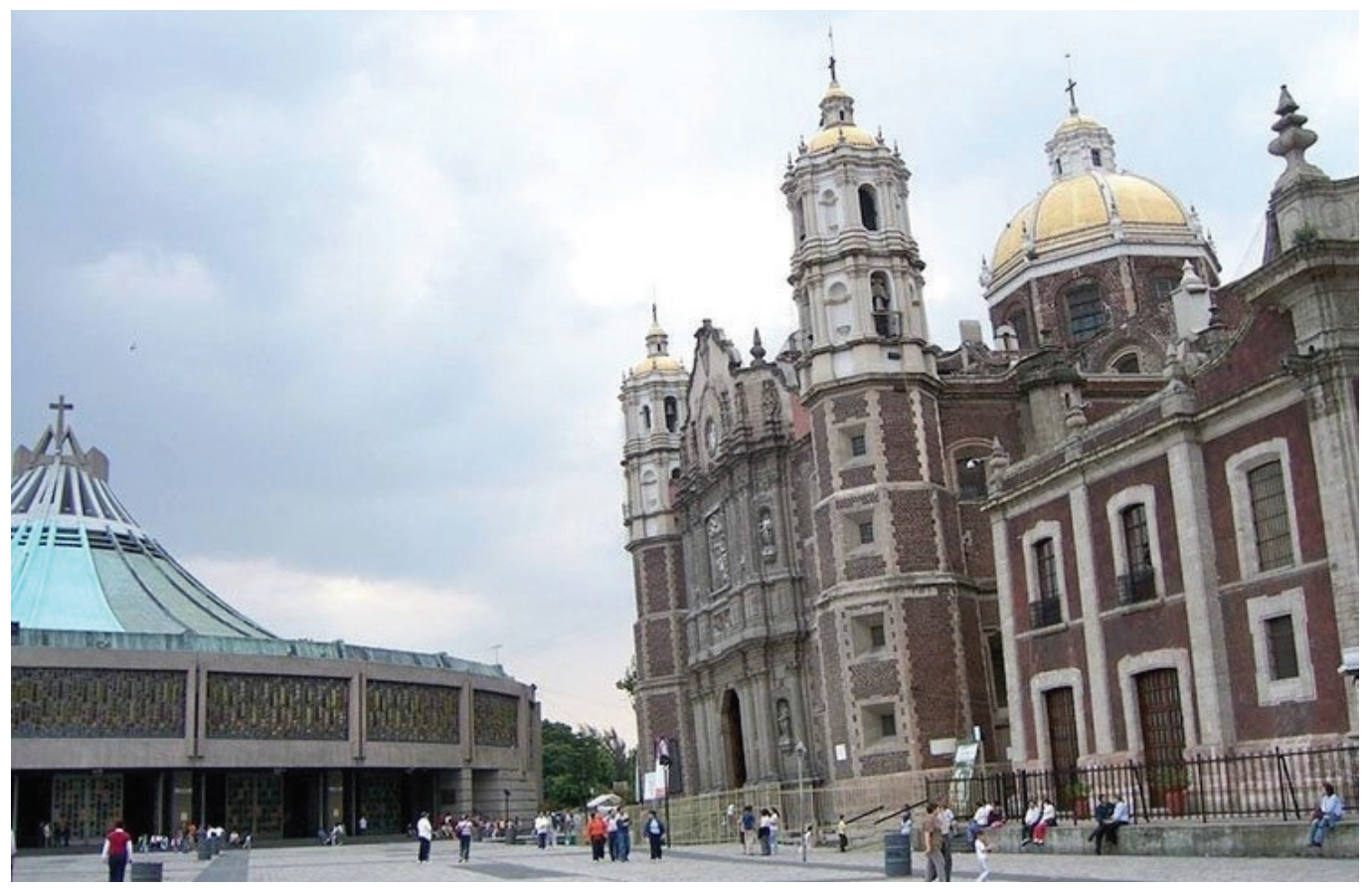

Şekil 3. Meksiko şehrinde bulunan Basilica de Santa Maria de Guadalupe'un yüzey çökmesi dolayısıyla eğilmesi (Google taramas1, 2018).

Şekil 3. Tilting of Basilica de Santa Maria de Guadalupe in Mexico city (Google search, 2018).

\section{Amerika Birleşik Devletleri}

Yeraltısuyu çekimi ile oluşan yüzey çökmesi problemi ABD de 1900'lü yıllardan beri araştırılmaktadır. Problemin boyutları ve yaptı̆̆1 hasarlar tespit edildikten sonra konu ciddi olarak araştırılmış, konferanslar düzenlenmiş ve bilimsel çalışmalar yapılmıştır. ABD Kaliforniya'da Santa Clara, DelanoTulare-Wasco, San Joaquin bölgelerinde ve Las Vegas vadisinde belirlenen ve saptanan problem birçok araştırmacı tarafından çalışılmıştır. Şekil 5'deki resim Kaliforniya'da Joaquin vadisinde yapılan yeraltısuyu üretimi sonucunda oluşan yüzey çökmesini en çarpıc1 şekilde gösteren örnek bir fotoğraftır. Yıllar boyunca yapılan yeraltısuyu çekimi sonucu yüzeyde oluşan çökme, kuyunun muhafaza borusu üzerinde net olarak görülmektedir. Poland öncülügünde yapılan araştırmalar ve hazırlanan raporlar sayesinde konunun tanımlanması ve çökmenin durdurulması yönünde önemli aşamalar kaydedilmiştir. ABD Jeolojik Araştırma grubu tarafından konu ayrıntılı olarak araştırılmış ve yüzey çökmesi probleminin çözümüne yönelik olarak yapılan çalışmalar (akifer sisteminin tanımlanması, bölgesel değerlendirmeler, mekanizmayı kontrol eden proseslerin analizi ve geçmiş ve gelecekteki akım ve çökme mekanizmalarının davranışları gibi) Galloway ve Sneed (2013) tarafından özetlenmiştir (Rappleye, 1933; Tolman ve Poland, 1940; Ingerson, 1941; Poland ve Davis, 1956; Poland, 1958; 1960; 1961; Poland vd., 1959; Poland ve Davis, 1969; Çorapçığlu ve Brutsaert, 1977; Poland, 1984; Li ve Helm, 1997; Riley, 1998; Galloway ve Sneed, 2013; Gambolati ve Teatini, 2015; Lei vd., 2015; Faunt vd., 2016). 


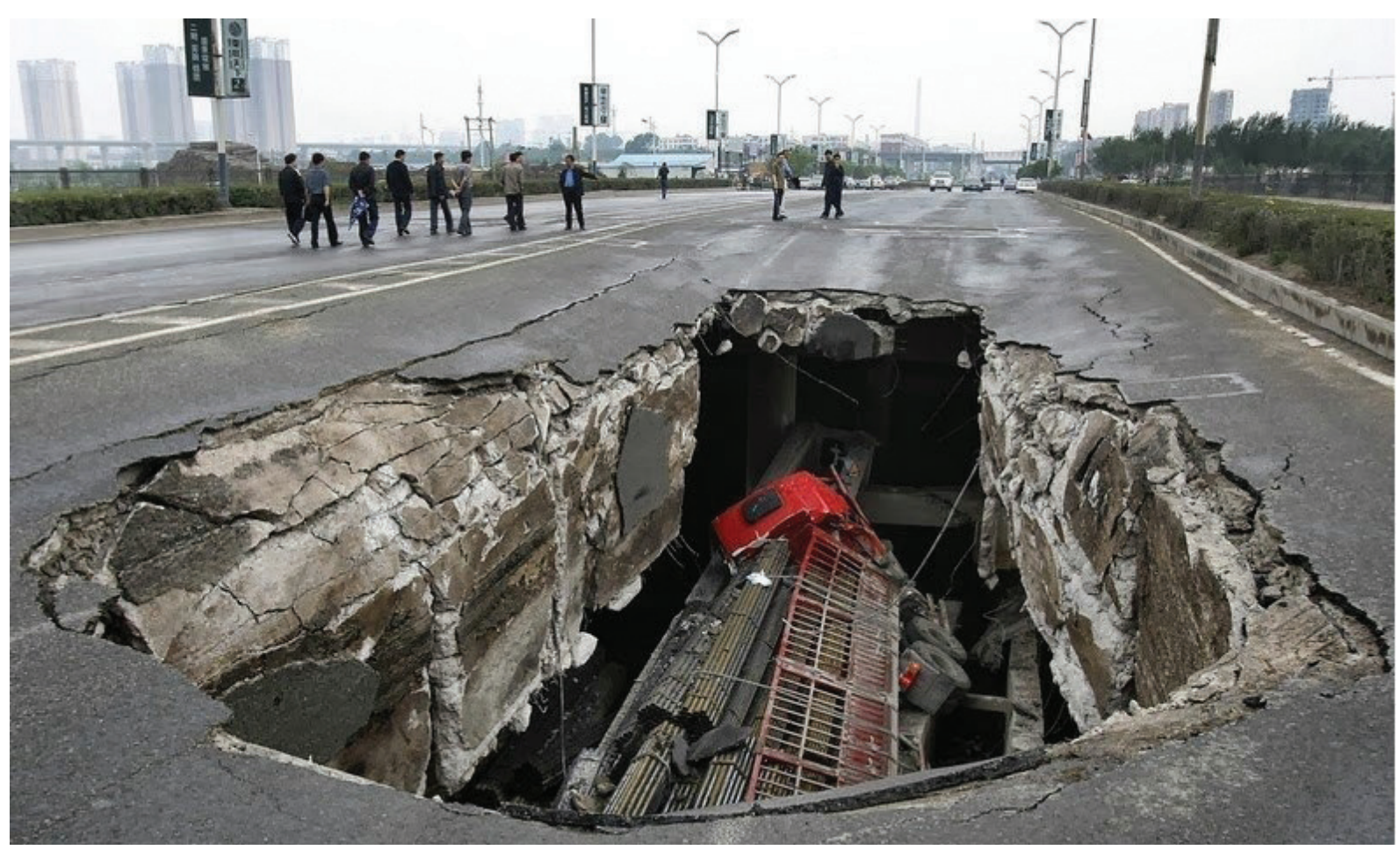

Şekil 4. Chanchun (Çin) şehrinde oluşan yüzey çökmesinin yaptığı hasar (Google taraması).

Figure 4. The damage caused by surface subsidence in Chanchun city, China (Google search).

\section{Ittalya}

İtalya'da yapılan yüzey çökmesi ile ilgili araştırmalar ilk yıllarda turizm potansiyeli nedeniyle Venedik şehri özelinde yoğunlaşmış ve daha sonraları diğer bölgelerdeki yoğun endüstriyel faaliyetlere bağlı artan yüzey deformasyonları konunun ülke geneline yayılmasına neden olmuştur. Venedik şehrinde ve Po ovasinda, Emilia-Romagna ve Ravenna bölgesinde ve Kuzey Adriyatik sahalarında meydana gelen yüzey çökmesi problemlerini araştırmak üzere 1970'li yıllardan itibaren çok sayıda araştırma yapılmış ve adı geçen bölgelerdeki çökme problemlerinin mekanik olarak tanımlanması ve sayısal modelleme konuları ayrıntılı olarak incelenmiştir (Gambolati ve Freeze, 1973; Gambolati vd., 1974; Lewis ve Shrefler, 1978; Gambolati vd., 1991, Gambolati vd., 2000; Gambolati vd., 2001; Teatini vd, 2005, Teatini vd., 2006, Castelletto vd., 2008; Settari vd., 2008; Gambolati ve Teatini, 2015). Bunlar arasında Gambolati ve ekibinin yaptığı çalışmalar önemli bir yer tutmaktadır ve yüzey çökmesi probleminin mekanik olarak açıklanmasında ve problemin sayısal olarak çözümündeki araştırmalarda bilimsel anlamda önemli katkılar sunmaktadırlar.

Lewis ve Schreffler (1978), yeraltısuyu çekimi sonucu Venedik'te meydana gelen yüzey çökmesi problemini modellemek için tam etkileşimli bir sonlu elemanlar yöntemi geliştirmiş ve model sonuçlarının bölgedeki çökmeyi çok başarılı şekilde modellediklerini belirtmişlerdir. Gambolati vd. (1991), İtalya'nın Ravenna bölgesindeki yüzey çökmesinin (19501986 y1lları arasında toplam $1.30 \mathrm{~m}$ ) yeraltısuyu 
çekimi sonucu akitardda ve rezervuarda oluşan kompaksiyon nedeniyle ve bölgedeki gaz kuyularından yapılan üretim sonucu oluştuğunu vurgulamaktadır. Gambolati vd. (2000), Po ovasındaki yüzey çökmesi problemini temel almışlar ve yeraltısuyu akım denklemi ile poroz ortam deformasyonu ilişkilerinin etkileşimli olarak ve bağımsız olarak çözülmesini sonlu elemanlar yöntemini kullanarak incelemişlerdir. Gambolati vd. (2001) tarafindan petrol ve gaz sahalarında oluşan yüzey çökmesinin tahmin edilmesi için iki farklı mekanik yöntem kullanılmış ve bu iki yaklaşımla oluşturulan denklemler özetlenerek tartışılmıştır. Settari vd. (2005; 2008), kuzey Adriyatik'te bulunan rezervuarda gaz üretimi sonucu oluşan yüzey çökmesini çalışmışlardır. Teatini vd. (2005) tarafından Ravenna bölgesindeki yüzey çökmesi probleminin yaklaşık bir asırdır devam ettiği ve bu hareketle ilgili bilgi birikimi sonunda oluşan 1987-2002 y1lları arasındaki verilerin CBS ortamına aktarılarak çökmenin boyutları ve bölgedeki dağılımı yönünde değerlendirildiğini belirtmektedir. Teatini vd. (2006), İtalya'da Po ovasinda bulunan Emilia Romagna bölgesinde ekonomik nedenler ve turizm nedeniyle yapılan yoğun miktarda yeraltısuyu çekimlerinin yüzey çökmelerine neden olduğunu vurgulamakta ve yüzey suyu kullanımlarının bu çökmeyi yavaşlattığını ancak yüzey çökmesinin devam ettiğini belirtmektedirler. Castelletto vd. (2008) araştırmalarında, Venedik şehrinin kurtarılmasına yönelik olası projeleri tartışmışlardır. Enjeksiyon yapılarak şehrin yükseltilmesi projesi değerlendirilmekte ve bu konu ile ilgili olarak yapılması gerekli araştırmalar irdelenmektedir.

Gambolati ve Teatini (2015), yeraltısuyu çekimi/enjeksiyonu sonucu oluşan yüzey çökmesi/yükselimi, yüzeyde oluşan kırıklar, dolaylı olarak gelişen sismik aktiviteler konularını değerlendirmekte ve konu ile ilgili tarihsel gelişimi dünyanın değişik bölgelerinden örneklerle aktarmaktadırlar. Diğer taraftan Gambolati ve ekibinin Venedik Lagünü bölgesinde yaptığ 1 modelleme (sonlu elemanlar) çalışmalarının 1974'den 2015'e kadar olan gelişimi anlatılmaktadır.

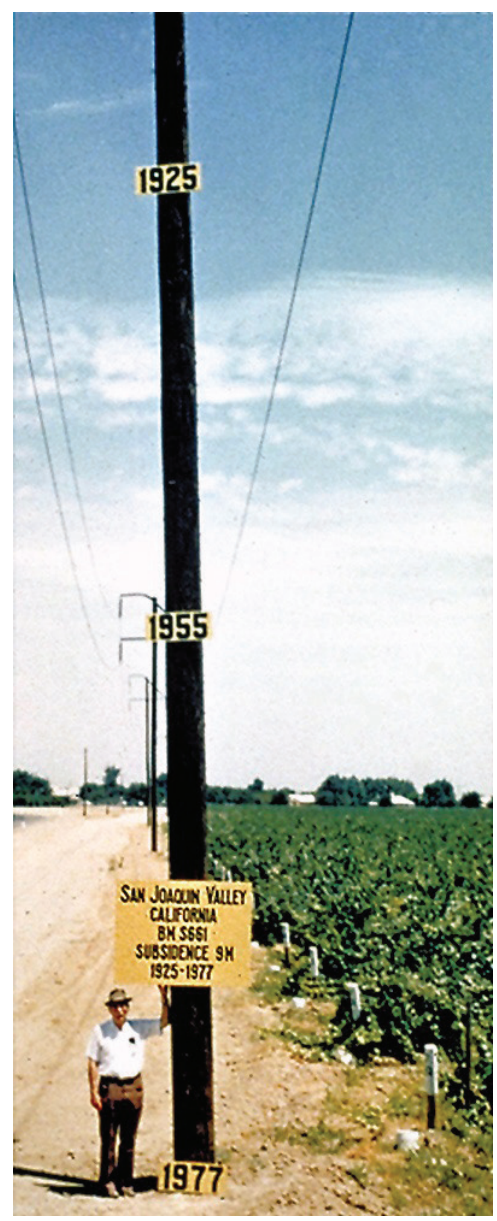

Şekil 5. ABD San Joaquin vadisinde değişik yıllarda ölçülen yüzey çökmesinin geçmişte açılan su kuyusunun çelik borusu yardımı ile tespit edilmesi (Poland, 1984).

Figure 5. Surface subsidence detected by the help of a steel pipe in a previously drilled water well in San Joaquin valley in USA in different years (Poland, 1984). 


\section{İspanya}

Ezquerro vd. (2014), Madrid (İspanya) akiferinde yapılan yeraltısuyu çekimi sonucu yüzeyde oluşan deformasyon araştırmalarında "Düzenli saçılımlı ölçme tekniği (PSI)" nin kullanıldığ 1 iki set Sentetik Aralıklı Radar (SAR) verileri kullanmışlardır. Yapılan gözlemlerde elastik ve elastik olmayan deplasmanlar ayrılmış ve elastik olanların elastik olmayan deplasmanlara göre 4 kat fazla olduğu gözlenmiştir. Değerlendirmeler deplasman davranışının elastik benzeri olduğunu göstermiş ve akiferin deplasmanı geri kazandığı dönemde geçmişte yapılan yeraltısuyu çekimi sırasında oluşan yüzey çökmesinin yükselim ile geri kazanıldığ1 gözlenmiştir. 1992-2010 yılları arasındaki davranışı modelleme çalışmalarında PSI deplasman ölçümleri ile model sonuçlarının doğrulandığı ve modelleme çalışmaları için \%13 lük bir hata tespit edildiği ve bu durumun düşük permeabiliteli ince taneli birimlerde oluşan elastik olmayan deplasmanlar nedeniyle oluştuğu belirtilmiştir.

\section{Meksika}

Meksika yeraltı suyu çekimi sonucu meydana gelen yüzey çökmesi problemini ciddi boyutlarda yaşayan bir ülkedir. Şekil 3, Meksiko şehrinde bulunan tarihi Basilica de Santa Maria de Guadalupe'un yeraltı suyu çekimi ile nasıl etkilendiğini göstermektedir. Ayrıca çökmenin boyutlarını göstermesi açısından Şekil 3 önemli bir delil olarak sunulabilir.

Meksiko şehrinde meydana gelen yüzey çökmesinden ilk kez Domenico ve Mifflin (1965)'de bahsedilmektedir ve etkin gerilmenin yeraltı suyu çekilmesi sonucu yükseldiği ve bu durumun yüzeyde ölçülebilir düzeyde deformasyonun (çökmenin) oluşmasına neden olduğu anlatılmaktadır. 1990'lı y1llarda OrtegaGuerrero vd. (1993), Ortega-Guerrero vd. (1999) ve Ortiz-Zamora ve Ortega-Guerrero (2010) yaptıkları çalışmalarda, Meksiko şehrindeki yüzey çökmesini araştırmışlar, Meksiko şehrinde Chalco baseninde bulunan akifer/akitard da meydana gelen çökmeyi çalışmışlar ve bir boyutlu matematiksel model yardımı ile değişik üretim koşulları altında meydana gelebilecek çökmeyi tahmin etmişlerdir. Calderhead vd. (2012) araştırmalarında Meksika Toluca vadisinde yeraltısuyu çekimi ile oluşan yüzey çökmesini üç boyutlu yeraltısuyu akım modeli ve tek boyutlu kompaksiyon modeli ile çalışmışlardır. Çökmeyi minimize etmek için değişik senaryolar denemişler ve beslenme, diğer havzalara su gönderme, pompa merkezlerinin yerlerini değiştirme ve yerel tüketim gibi parametrelerle uygun çözümleri araştırmışlardır. PachecoMartinez vd. (2013) Aguascalientes vadisinde aşırı çekim sonucu oluşan yüzey çökmesini çalışmışlar, yüzey çökmesinin Aguascalientes şehrinde kamu ve özel mülklerde ve altyapılarda ciddi hasarlara neden olduğunu vurgulamışlardır.

\section{İran}

Çok fazla örnek olmamakla birlikte; Kumarcı vd. (2008) WTAQ programını kullanarak sonlu elemanlar yöntemi ile basınç düşümü sonunda oluşan çökmeyi zamana bağlı elastik davranış kullanarak modellemiş ve İran'da Sirjan ve Shahrekord'da uygulamışlardır. Benzer şekilde Jafari vd. (2016) geliştirdikleri MOD-FLOW programını İran'da Saveh sahasına uygulamışlar ve model çalışmaları sonunda InSAR, extensometre ve sayısal model sonuçlarının birbirleri ile uyumlu olduklarını ifade etmişlerdir. 
Karahanoğlu

\section{Çin}

Çin, yeraltusuyu çekimi ile oluşan yüzey çökmesi probleminden yoğun bir şekilde etkilenmektedir. 1920 y1lında Shangay'da gözlenen yeraltısuyu çekimi sonucu oluşan yüzey çökmesi problemi ileri y1llarda diğer şehirlerde de tespit edilmiş ve bu konuda birçok araştırma yapılmıştır (Pei vd., 2000; Hua vd., 2004; Kim, 2005; Shi vd., 2007; Xu vd., 2008; Wu vd., 2009; Shen ve Xu, 2011; Xu vd., 2012; Zhang vd., 2015; Lin vd., 2015; Ye vd., 2016a; Ye vd., 2016b). Ülkenin sanayi atılımı ile hızla artış gösteren yeraltısuyu çekimi birçok bölgede yüzey çökmesi problemi oluşturmuş ve dolaylı olarak şehirlerin altyap1 sistemlerinde hasarlar meydana getirmiştir (Şekil 4). Bu durum Çizelge 2' de ayrınt1l1 olarak verilmekte ve tehlikenin boyutları her bir şehir temelinde özetlenmektedir.

Ülkede meydana gelen yüzey çökmesi problemi konusunda yapılan bilimsel araştırmalar 1990’11 yılların sonuna doğru literatürde yer almaya başlamıştır. Bu anlamda Shearer (1998) tarafından yapılan çalışma, model çalışmaları arasında öncü olarak yer almaktadır. MODFLOW programı kullanılarak yapılan araştırmada, Tianjin bölgesinde 1950 yılından beri gözlenen yüzey çökmesi modellenmiş ve değişik üretim senaryoları kullanılarak 2020 yılı için yüzey çökmesi tahminleri yapılmıştır.

Pei vd. (2000), üç boyutlu sayısal model geliştirerek Çin'in Suzhou şehrinde meydana gelen yeraltısuyu çekimine bağlı yüzey çökmesi problemini modellemişlerdir. Yeraltısuyu akımı ve doğrusal olmayan konsolidasyon yaklaşımı öngörülerek hazırlanan model denklemleri sonlu farklar yöntemi kullanılarak çözülmüştür.

Hu vd. (2004), Çin'in değişik bölgelerinde oluşan çökme olaylarını bölgesel ve tarihsel olarak anlatmaktadır. Çökme değerleri, şehirler ve bölgeler için tablolar şeklinde verilmekte ve çökmenin yoğun olduğu bölgelerde yapılan önleme/durdurma projeleri tanıtılmaktadır.

Wu vd. (2009), Çin'in Su-Xi-Chang bölgesinde meydana gelen yüzey çökmesi problemini araştırmak için geliştirdikleri 3 boyutlu sonlu elemanlar modelini bölgeye uygulamışlar ve 1996-2004 arası dönem için elde edilen sonuçların gözlenen değerlerle iyi bir uyum sağladığını ifade edilmiştir.

2010 y1lından sonra Shangay şehrindeki çökme probleminin şehir altyapısını olumsuz etkilemesi nedeniyle konunun araştırılması önem kazanmış ve yapılan çalışmalar makale olarak sunulmuştur. Shen ve Xu (2011) yaptıkları araştırmada çekilen su miktarı, su çekilen seviye ve su çekilen bölgenin yüzey çökmesine etkisini irdelemişlerdir. Ye vd. (2011), çok ölçekli sonlu elemanlar modeli ile 1986-1988 arasında gözlenen yüzey çökmesini araştırmışlardır. Xu vd. (2012), üç boyutlu su akımı ve tek boyutlu konsolidasyon sayısal modeli çalışmalarında bölgedeki çok tabakalı akifer ve akitard sisteminde meydana gelen sızma ve yüzey çökmesi olgularını çalışmışlardır. Zhang vd. (2015), yeraltısuyu çekimi ve suyun geri basımı sonucu gelişen yüzey çökmesi ve yüzey yükselmesi mekanizmalarını arazi ve laboratuvar değerlerini kullanarak çalışmışlardır. Ye vd. (2016) geliştirdikleri modelde, birbirleri ile tam etkileşimli 3 boyutlu yeraltısuyu akımı ve 3 boyutlu akifer-sistem deplasmanı yaklaşımını kullanmışlar ve 1979-1995 yılları arasındaki durumu simüle etmişlerdir.

Lin vd. (2015), Pekin'in kuzey bölgesinde 2003-2010 yılları arasında meydana gelen yüzey çökmesinin nedenlerini araştırmayı, bu olayın gelişmesini tanımlamayı ve tetikleyici faktörleri belirlemeyi amaçlamışlardır. $\mathrm{Bu}$ amaçla kuyu ekstensometre verileri, interferometri'den elde edilen yüzey çökmeleri, yeraltı su seviyeleri, 
hidrojeolojik bilgiler ve Landsat TM görüntüleri kullanılarak yüzey çökmesinin mekan ve zaman boyutundaki yapıları araştırılmış ve yüzey çökmesinin yeraltısuyu seviye değişimleriyle, sıkıştırılabilen tabaka kalınlığ 1 ve şehirleşme ile olan ilişkileri incelenmiştir.

\section{Tayvan}

Lin vd. (2015), hazırladikları 3 boyutlu akım ve tek boyutlu deformasyon modelleri ile çok tabakalı sistem için sayısal modelleme çalışması yapmışlar, sonuçlarını analitik model ile karşılaştırmışlar ve modellerini Tayvan'da Yuanchang bölgesinde uygulamışlardır. Wang vd. (2015) geliştirdikleri stokastik poroelastik modelle aynı sahayı modellemişlerdir. Liu vd. (2004), Tayvan Choshui alüvyon yelpazesinde aşırı su çekimi ile oluşan deformasyonu çalışmışlar ve bölgede bulunan killerin Terzaghi konsolidasyon teorisine uygun davrandığını ve kumlu seviyelerde gözlenen kalıcı deformasyonların elasto-plastik şekilde davrandığını belirtmişlerdir.

\section{Vietnam}

Nguyen ve Helm (1998) tarafindan Hanoi' de 1988 'den beri gözlenen ve aşırı su çekimi sonucu su seviyelerinde $35 \mathrm{~m}$ düşüş meydana geldiği ve evlerde, fabrikalarda ve okullarda $10-15 \mathrm{~cm}$ ye yakın yüzey çökmesi olduğu belirtilmektedir.

\section{Yunanistan}

Yunanistan yeraltısuyu çekimi sonucu meydana gelen yüzey çökmesi problemi ile 1960’lı y1llardan beri uğraşmaktadır. Selanik havzasının değişik kesimlerinde yapılan yoğun çekimler bu alanlarda yüzey çökmesine neden olmuş ve birçok araştırmacı bu konuda çalışmalar yapmıştır (Stiros, 2001; Kontogianni vd., 2007; Loupasakis ve Rozos, 2009; Sideri ve Modis, 2014).

Stiros (2001), Yunanistan'da KalachoriSelanik bölgesinde yüzey çökmesinin oluşumunun 1960'larda başladığını ve konu ile ilgili gelişmeleri aktarmaktadır. Kontogianni vd. (2007), Orta Yunanistan'da Selanik (Thesally) havzasında meydana gelen yüzey çökmesinin aşırı yeraltısuyu çekimi sonucu gevşek sedimanlarda meydana gelen kompaksiyon ile oluştuğunu ifade etmişlerdir. Psimoulis vd. (2007), son 50 y1lda oluşan çökmenin $3.5 \mathrm{~m}$ dolaylarında olduğunu ve yoğun çekimlerle çökmenin arttığını vurgulamaktadır.

Loupasakis ve Rozos (2009), Yunanistan'da oluşan yüzey çökmesi problemini sonlu elemanlar yöntemini kullanarak araştırmışlardır. Yunanistan'ın önemli endüstri merkezlerinden birisi olan Selânik bölgesinde Kalachori köyü yakınlarında gözlenen yeraltısuyu çekimine bağlı yüzey çökmesi çalışılmıştır.

Paleologos ve Mertikas (2013), Yunanistan genelinde tespit edilen yüzey çökmesi problemlerini ve bu konuda yapılan çalışmaları özetlemekte ve bu konuda ülkenin değişik bölgelerindeki durumu anlatmaktadır. Sideri ve Modis (2014), Batı Selanik bölgesinde oluşan yüzey çökmesini araştırmıştır.

\section{Türkiye}

Ülkemizde yeraltısuyu havzalarından çekilen yeraltısuyu içme suyu, sulama suyu ve sanayi suyu ihtiyaçlarını karşılamak amacıyla yoğun bir şekilde kullanılmaktadır. Böylelikle yeraltısuyu havzalarında su seviyeleri hızlı bir şekilde düşmekte ve akiferlerdeki kuvvet dengeleri olumsuz bir şekilde değişmektedir. Diğger taraftan Büyük Menderes havzasinda bulunan jeotermal sahalardan sicak su ve buhar üretimi yapılarak 
Karahanoğlu

santrallerden elektrik üretimi elde edilmekte ve sicak sular seracilıkta kullanılmaktadır. Ayrica birçok bölgede jeotermal sahalardan üretilen sıcak sulardan kent 1sıtmacılığında yararlanılmaktadır (İzmir Balçova sahası, Kızılcahamam sahası ve Edremit jeotermal sahası gibi). Böylece akiferler ve jeotermal sahalar yoğun üretim yapılarak işletilmektedir. Birçok bölgede yapılan yoğun yeraltısuyu çekimleri sonucunda su seviyelerinde ciddi boyutlarda düşüş olduğu belirtilmekle birlikte, bir kaç araştırma dışında henüz yüzey çökmesi konusunda yapılan gözlem veya tespit bulunmamaktadır. Elde olan mevcut bilgilerden şu iki çalışma aktarılmaktadır.

Çelik ve Afşin (1998), Niğde Sazlıca'da gölden su çekimi sonucu oluşan yüzey çökmesini araştırmışlar ve gölden yapılan su çekiminin yüzey çökmesi oluşumuna direkt etkisi olduğunu vurgulamışlardır.

Üstün vd. (2015), araştırmalarında, Konya ovasında yeraltısuyu çekimi ile oluşan yüzey çökmelerini GPS ve DInSAR yöntemleri ile çalışmışlar ve yüzey çökmesinin yılda $1-4 \mathrm{~cm}$ seviyesinde olduğunu tespit etmişlerdir.

\section{SAYISAL MODELLEME}

Gözenekli ortamda yeraltısuyu hareketi ve buna bağlı gelişen deformasyon mekanizması, akiferlerde ve rezervuarlarda ortak ve tam etkileşimli olarak süregelen hidrodinamik sistemi ifade etmektedir. Uzun yıllar boyunca doğal süreçlerle dengeye ulaşmış olan bu hidrodinamik sistem, üretim yapilarak bozulmakta ve tüm sistem gelişen değişikliklere bağlı olarak yeni denge koşullarına ulaşmaya zorlanmaktadır. Modelleme çalışmaları ile bu tür değişikliklerin bilimsel yöntemler kullanılarak açıklanması ve bazı değişkenler ve parametreler yardımı ile ortamdaki gelişmelerin matematiksel ifadeler ile açıklanması gerekli olmaktadır. Bir bütün olarak ele alınan sistemin içindeki hareketlerin (değişikliklerin) diferansiyel denklemler kullanılarak tanımlanmasının yanında, tüm sistemin sınırlarındaki değişikliklerin de benzer şekilde ifade edilmesi gerekmektedir. Böylelikle sistemin doğal denge koşullarından (başlangıç koşulları) başlayarak yeni denge koşullarına ulaşacağı süreçte gelişecek olan değişikliklerin modellenmesi planlanmaktadır. $\mathrm{Bu}$ amaçla oluşturulan matematiksel ifadelerde, söz konusu hidrodinamik sistemin değişkenleri olarak gözenekli ortamdaki su basıncı (su yükü) ve gözenekli ortamın birim deformasyonu (deplasman) kullanılmaktadır. Bunlara ek olarak sistemin fiziksel ve mekanik özelliklerini yansitan parametreler (hidrolik iletkenlik, gözeneklilik, sıkıştırılabilme katsayısı, depolama katsayısı ve deformasyon parametreleri, elastik modüller) bazen sabit bazen değişkenlere bağl1 olarak ifade edilerek model denklemleri içinde yer almaktadir.

Yeraltısuyu çekimi ile oluşan yüzey çökmesinin hidromekanik özelliklerinin araştırılabilmesi için yeraltısuyu hareketi ve akifer/akitard deformasyon ilişkilerinin bilimsel olarak tanımlanması gerekmektedir. Bu konuda Biot'nun geliştirdiği üç boyutlu matematiksel denklemler (Biot, 1941; 1955) yeraltısuyu akımı ile deformasyon mekanizmalarını birbirlerine bağlı olarak ifade etmektedir. Böylece ilk kez yeraltısuyu çekimi ile oluşan yüzey çökmesinin matematiksel denklemler kullanılarak ifade edilmiş olması bu konuda önemli bir gelişme olarak kaydedilmektedir. Zamana bağlı yeraltısuyu akım denklemi, 
$\mathrm{K}\left[\frac{\partial^{2} \mathrm{~h}}{\partial \mathrm{x}^{2}}+\frac{\partial^{2} \mathrm{~h}}{\partial \mathrm{y}^{2}}+\frac{\partial^{2} \mathrm{~h}}{\partial \mathrm{z}^{2}}\right]=\frac{\partial \mathrm{h}}{\partial \mathrm{t}}\left[\frac{\partial \mathrm{u}_{\mathrm{x}}}{\partial \mathrm{x}}+\frac{\partial \mathrm{u}_{\mathrm{y}}}{\partial \mathrm{y}}+\frac{\partial \mathrm{u}_{\mathrm{z}}}{\partial \mathrm{z}}\right]+\mathrm{S} \mathrm{s}_{\mathrm{w}} \frac{\partial \mathrm{h}}{\partial \mathrm{t}}$

$\mathrm{K}$ : hidrolik iletkenlik

$\mathrm{S} \mathrm{s}_{\mathrm{w}}$ : Suyun birim depolamas1

Biot'nun geliştirdiği üç boyutlu poroelastik denklemleri aşağıda verilen şekli ile gözenekli ortamda yeraltısuyu yükündeki değişim ( $\mathrm{h}$ ) ve ortamda gelişecek deplasmanlar cinsinden izotrop koşul için yazılmıştır.
Yeraltısuyu akım denklemi ve denge denklemleri dört adet denklemden oluşmaktadır ve bu denklemlerde $h$, yeraltısuyu yükü ve $\mathrm{x}, \mathrm{y}, \mathrm{z}$ yönündeki deplasmanlar $\left(\mathrm{u}_{\mathrm{x}}, \mathrm{u}_{\mathrm{y}}\right.$ ve $u_{z}$ ) bilinmeyenler olarak belirlenmiştir.

$$
\begin{aligned}
& (\lambda+\mathrm{G}) \frac{\partial}{\partial \mathrm{x}}\left[\frac{\partial \mathrm{u}_{\mathrm{x}}}{\partial \mathrm{x}}+\frac{\partial \mathrm{u}_{\mathrm{y}}}{\partial \mathrm{y}}+\frac{\partial \mathrm{u}_{\mathrm{z}}}{\partial \mathrm{z}}\right]+\mathrm{G}\left[\frac{\partial^{2} \mathrm{u}_{\mathrm{x}}}{\partial \mathrm{x}^{2}}+\frac{\partial^{2} \mathrm{u}_{\mathrm{x}}}{\partial \mathrm{y}^{2}}+\frac{\partial^{2} \mathrm{u}_{\mathrm{x}}}{\partial \mathrm{z}^{2}}\right]-\rho_{\mathrm{w}} \mathrm{g} \frac{\partial \mathrm{h}}{\partial \mathrm{x}}=0 \\
& (\lambda+G) \frac{\partial}{\partial y}\left[\frac{\partial u_{x}}{\partial x}+\frac{\partial u_{y}}{\partial y}+\frac{\partial u_{z}}{\partial z}\right]+G\left[\frac{\partial^{2} u_{y}}{\partial x^{2}}+\frac{\partial^{2} u_{y}}{\partial y^{2}}+\frac{\partial^{2} u_{y}}{\partial z^{2}}\right]-\rho_{w} g \frac{\partial h}{\partial y}=0 \\
& (\lambda+\mathrm{G}) \frac{\partial}{\partial \mathrm{z}}\left[\frac{\partial \mathrm{u}_{\mathrm{x}}}{\partial \mathrm{x}}+\frac{\partial \mathrm{u}_{\mathrm{y}}}{\partial \mathrm{y}}+\frac{\partial \mathrm{u}_{\mathrm{z}}}{\partial \mathrm{z}}\right]+\mathrm{G}\left[\frac{\partial^{2} \mathrm{u}_{\mathrm{z}}}{\partial \mathrm{x}^{2}}+\frac{\partial^{2} \mathrm{u}_{\mathrm{z}}}{\partial \mathrm{y}^{2}}+\frac{\partial^{2} \mathrm{u}_{\mathrm{z}}}{\partial \mathrm{z}^{2}}\right]-\rho_{\mathrm{w}} \mathrm{g} \frac{\partial \mathrm{h}}{\partial \mathrm{z}}=0
\end{aligned}
$$

Burada

$\lambda$ : Lame sabiti,

$\mathrm{G}$ : Makaslama modülü

$\mathrm{Bu}$ denklemler (1 ve 2 nolu denklemler) oluşturulurken kuvvetlerin dengede olması prensibi esas alınmış ve ortamın homojen olduğu, birim deformasyon ve deplasman ilişkilerinin geçerli olduğu ve katı tanelerin sıkıştırılamaz olduğu ve elastik davranış gösterdiği kabul edilmiştir (Galloway ve Burbey, 2011).
Denklemler birbirleri ile tam etkileşimli olarak oluşturulmuştur ve bu denklem sisteminin uygun sınır ve başlangıç koşulları altında eşzamanlı çözümü, adı geçen değişkenlerin zaman ve uzay boyutundaki değerlerini vermektedir. $\mathrm{Bu}$ tür modellerin çalışma sahasına kalibre edilerek uygulanması ve dolayısı ile sahanın 
Karahanoğlu

hidrodinamik davranışının sayısal model ile tanımlanabilmesi çok önemli bir aşamayı oluşturmaktadır. Böyle bir modelin değişik amaçlar (sahanın kapasitesinin belirlenmesi, değişik üretim senaryolarının denenmesi, vb.) için kullanılabilinmesi sağlanmakta ve bu uygulama sahanın sürdürülebilir üretim koşullarının belirlenmesinde vazgeçilemez bir rol oynamaktadir.

Yeraltısuyu akımını ve yüzey çökmesini matematiksel olarak ifade eden bu denklemler geliştirilen sayısal modelin matematiksel model kısmını oluşturmaktadır. Bu denklem sisteminin çözülebilmesi için akifer/rezervuar sisteminin hidrodinamik olarak başlangıç ve sınır koşullarının değişkenler yardımı ile belirlenmesi gerekmektedir. Böylelikle matematiksel model tamamlanmış olmakta ve Sonlu Elemanlar yönteminin uygulaması ile diferansiyel denklemler cebirsel denklem sistemlerine dönüştürülerek değişkenlerin zaman ve mekan boyutundaki değerleri cebirsel denklemlerin çözümü ile elde edilmektedir.

\section{Sonlu Elemanlar Çözümü}

Sonlu elemanlar yöntemi, diferansiyel denklemlerin sayısal çözümünde başarılı olarak uygulanan bir yöntemdir (Zienkiewicz, 1977).
Çözüm ortamının küçük elemanlara bölünmesi ve bilinmeyen çözüm fonksiyonunun eleman içinde bilinen fonksiyon ile ifade edilmesi esasına dayanan bu yöntemle, bilinmeyenlerin zaman ve mekan içindeki dağılımları elde edilmektedir. Sonlu elemanlar yönteminin denklem sistemlerine uygulanması iki farklı yaklaşım ile yapılmaktadır. Birinci yöntem 'Varyasyonel Yöntem' olarak bilinir ve matematik yaklaşımlarla diferansiyel denklemler (sistemi tanımlayan model denklemleri) sonlu eleman denklemlerine dönüştürülmektedir. İkinci yöntem 'Weighted residual-Ağırlıkl1 farklar' yöntemi olarak bilinir ve elemanlardaki bilinen fonksiyonlar ile çözüm fonksiyonları arasındaki farkların minimize edilmesi prensibine dayanmaktadır. Böylelikle elde edilen eleman denklemleri elemanların model ağı içindeki konumlarına göre birleştirilerek genel denklem sistemleri elde edilmektedir. Başlangıç ve sınır koşullarının tanımlanması ile tamamlanan sayısal model, sistem değişkenlerinin (su yükü-basınç ve deplasman) çözüm ortamında dağılımlarının elde edilmesi (bilinmeyenlerin çözülmesi) için kullanılmaktadır.

Örnek olarak, iki boyutlu ortam için üçgen elemanların kullanılması durumunda eleman denklemleri (köşe noktaları i, j, k olan üçgen için) aşağıdaki şekilde yazılır;

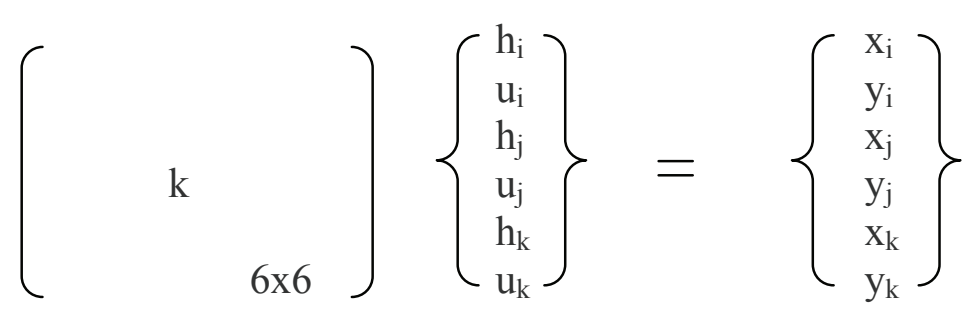


Eleman denkleminde (k) katsayı matriksi olup denklem sistemlerinde bulunan fiziksel ve mekanik parametreleri içermektedir ve üçgenin köşe noktaları ve bilinmeyen çarpımı kadar girdi içermektedir. (h ve u) denklemlerin bilinmeyenleri olan su yükü ve deplasman değişkenleridir. Denklemin sağ tarafinda bulunan $\mathrm{x}$ ve $\mathrm{y}$ sembolleri denklem sistemlerinde bulunan ve değerleri bilinen sayıları göstermektedir. Matriks şeklinde yazılan eleman denklemleri, alt1 adet denklemden ve alt1 adet bilinmeyenden oluşmaktadır. Eleman denklemleri elemanların ağ içindeki bağlantı durumuna göre birbirleri ile birleştirilerek genel denklemler elde edilmektedir. (m) sayısı kadar düğüm noktasının bulunduğu bir çözüm ortamında 2xm kadar denklem ve $2 \mathrm{xm}$ kadar bilinmeyeni olan genel denklemler oluşturulur ve uygun sınır koşulları ve başlangıç koşullarının uygulanması ile bu denklemler çözülerek bilinmeyenlerin değerleri ağ içindeki noktalarda elde edilir.
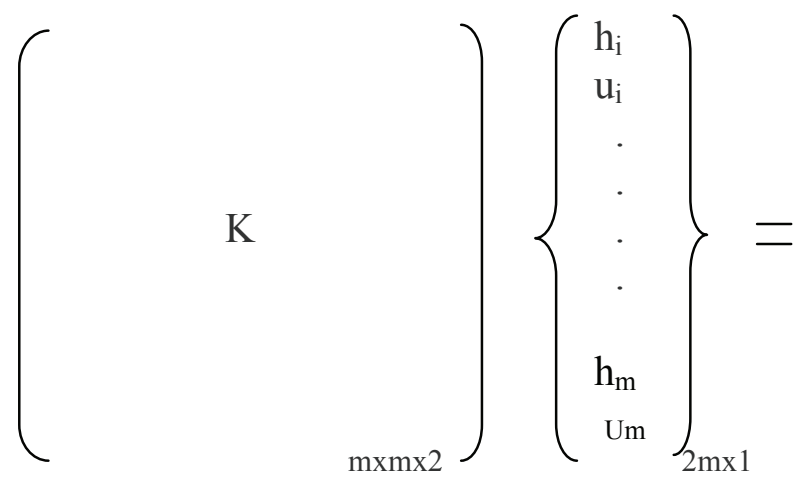

\section{DEĞERLENDİRMELER VE ÖNERILLER}

Yeraltısuyu çekimi ve buna bağlı yüzey çökmesi, uzun yıllardır araştırılan bir konudur ve birçok ülkede hem üretim politikalarını olumsuz etkilemekte hem de ciddi altyapı sorunlarına neden olmaktadır. Yüzey çökmesi olayının gerçekleşmesinde önemli payları olan akışkan hareketi ve deformasyon mekanizmalarının birbirleri ile olan ilişkileri araştırmacıların önemli konuları arasında yer almış ve problemin çözümüne yönelik çeşitli bilimsel çalışmalar yapılmıştır. Geçmiş yıllarda problemin tanımına ve nedenlerinin araştırılmasına yönlendirilen çalışmalar daha sonraki yıllarda yüzey çökmesinin durdurulmasını ve önlenmesini hedefleyen araştırmalar olmuştur. 1940'l1 yıllardan itibaren yeraltısuyu akımı ve yüzey çökmesinin birbirlerini tam etkileşimli olarak etkiledikleri bilinmektedir ve matematiksel olarak ifade edilen bu ilişki, ileri yıllarda sayısal yöntemler kullanılarak modellenmiştir. İlk modelleme çalışmalarında çökme hareketinin sadece düşey boyutu değerlendirilmiş, yakın zamanda yapılan çalışmalarda üç boyutlu deformasyon ilişkileri kullanılmıştır. Ayrıca çökme hareketinin sadece akifer/rezervuar birimi içerisinde olmayacağı aynı zamanda örtü kaya içindeki deformasyonun da önemli olabileceği

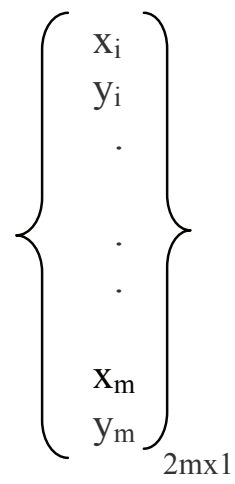

ileri sürülmüş ve bu konuyu kapsayan sayısal modeller geliştirilmiştir.

Yeraltından su çekimi ile oluşan yüzey çökmesi çoğu ülkede yüzeyde meydana gelen deformasyonlar sayesindebilimdünyasındayerini almış ve altyapı hasarlarına neden olmasından ötürü ayrıntılı olarak araştırılmıştır. Bu konuda 
Karahanoğlu

yapılan bilimsel araştırmaların temelinde çökme hareketinin izlenmesi ve deformasyon boyutlarının ölçülmesi yer almaktadır. Birçok araştırmada uzun y1llara dayanan ölçüm değerleri esas alınarak geliştirilen modellerin kalibrasyonu yapılmakta ve geleceğe yönelik tahminler yardımı ile problemin çözümüne yönelik senaryolar üretilmektedir. $\mathrm{Bu}$ nedenle çökme mekanizmasının dinamik boyutlarının ölçülmesi ve gelişmiş teknoloji içeren yöntemlerle izlenmesi problemin çözülmesi açısından çok önemlidir. $\mathrm{Bu}$ durum yoğun üretim yapılan yeraltısuyu havzalarında ve jeotermal sahalarda yüzey hareketlerinin devamlı olarak ölçülmesini ve gelecekte ciddi sorunlarla karşılaşmamak için olası yüzey deformasyonların izlenmesini gerekli kılmaktadır. Ayrıca deformasyon ilişkilerinin de ele alındığı sayısal modelleme çalışmaları yapılarak halen üretilmekte olan yeraltısuyu havzalarının ve jeotermal sahaların süregelen üretim senaryoları ile gelecekte yüzey çökmesi problemi ile karşılaşıp karşılaşmayacakları araştırılabilinir. Böylece yüzey çökmesi oluşumunu minimum düzeye indirecek en uygun üretim ve saha geliştirme koşulları elde edilmiş olacaktır.

\section{KAYNAKLAR}

Aboustit, B. L., Advani, S.H., Lee, J.K., 1985. Variational principles and finite element simulations for thermo-elastic consolidation. International Journal for Numerical and Analytical Methods in Geomechanics, 9, 45-69.

Bear, J., Çorapçığlu, M.Y., 1981a. Mathematicalmodel for regional land subsidence due to pumping. 1. Integrated aquifer subsidence equations based on vertical displacement only. Water Resources Research, 17(4), 937-946.

Bear, J., Çorapçığlu, M.Y., 1981b. Mathematicalmodel for regional land subsidence due to pumping. 2. Integrated aquifer subsidence equations for vertical and horizontal displacements. Water Resources Research, 17, 4, 947-958.

Bear, J., Çorapçığlu, M.Y., 1981c. A mathematicalmodel for consolidation in a thermoelastic aquifer due to hot water injection or pumping. Water Resources Research, 17, 3, 723-736.

Biot, M.A., 1941. General theory of 3 D consolidation. Journal of Applied Physics, 12, 155-164.

Biot, M.A., 1955. Theory of elasticity and consolidation for a porous anisotropic solid. Journal of Applied Physics, 26, 2, 182-185.

Burbey, T.J., Helm, D.C., 1999. Modeling threedimensional deformation in response to pumping of unconsolidated aquifers. Environmental \& Engineering Geoscience, 5, 2, 199-212.

Calderhead, AI., Martel, R., Garfias, J., Rivera, A., Therrien, R., 2012. Sustainable management for minimizing land subsidence of an over-pumped volcanic aquifer system: tools for policy design. Water Resources Management, 26, 7, 18471864.

Castelletto, N., Ferronato, M., Gambolati, G., Putti, M., Teatini, P., 2008. Can Venice be raised by pumping water underground? A pilot project to help decide. Water Resources Research, 44 (1), WO 1408

Chang, C.D., Mallman, E., Zoback, M. 2014. Timedependent subsidence associated with drainageinduced compaction in Gulf of Mexico shales bounding a severely depleted gas reservoir. AAPG Bulletin, 98, 6, 1145-1159.

Cheo, K. Lee, Sophie N. Fallou, Chiang C. Mei, 1992. Subsidence due to pumping from a soil stratum with a soft aquitard. Philosophical Transactions of The Royal Society of London Series A-Mathematical Physical and Engineering Sciences, 339, 1653, 193-230.

Çelik, M., Afşin, M., 1998. The role of hydrogeology in solution-subsidence development and its environmental impacts; a case-study for Sazlica (Niğde, Turkey). Environmental Geology, 36 (3-4), 335-342. 
Çorapçıŏlu, M. Y., 1984. Land subsidence-a stateof-the-art review. In: Bear J., Corapcioglu M.Y. (eds.) Fundamentals of Transport Phenomena in Porous Media. NATO ASI Series (Series E: Applied Sciences), Vol 82. Springer, Dordrecht.

Çorapcioglu, M.Y., Brutsaert, W., 1977. Viscoelastic aquifer model applied to subsidence due to pumping. Water Resources Research, 13(3), 597-604.

Domenico, P.A., Mifflin, M.D., 1965. Water from low permeability sediments and land subsidence. Water Resources Research, 1(4), 563-576.

Ezquerro, P., Herrera, G.,Marchamalo, M., Tomas, R., Bejar-Pizarro, M., Martinez, R., 2014. A quasielastic aquifer deformational behavior: Madrid aquifer case study. Journal of Hydrology, 519, 1192-1204.

Faunt, C.C., Sneed, M., Traum, J., Brandt, J.T., 2016. Water availability and land subsidence in the Central Valley, California, USA. Hydrogeology Journal, 24(3), 675-684.

Fuller, M.L., 1908. Summary of the controlling factors of artesian flows. U.S. Geol. Surv. Bull., 319, 44 pp.

Galloway, D.L., Burbey, T.J., 2011. Review: regional land subsidence accompanying groundwater extraction. Hydrogeology Journal, 19(8), 14591486.

Galloway, D.L, Sneed, M., 2013. Analysis and simulation of subsidence accompanying groundwater abstraction and compaction of susceptible aquifer systems in the USA. Boletin De La Sociedad Geologica Mexicana, 65, 123136.

Gambolati, G., Ferronato, M., Teatini, P., Deidda, R., Lecca, G., 2001. Finite element analysis of land subsidence above depleted reservoirs with pore pressure gradient and total stress formulations. International Journal for Numerical and Analytical Methods in Geomechanics, 25(4), 307-327.

Gambolati, G., Freeze, R.A., 1973. Mathematical simulation of the subsidence of Venice-1, Theory. Water Resources Research, 9(3), 721733.
Gambolati, G., Gatto, P., Freeze, R.A., 1974. Mathematical simulation of the subsidence of Venice-2, Water Resources Research, 10(3), 563-577.

Gambolati, G., Ricceri, G., Bertoni, W., Brighenti, G., Vuillermin, E., 1991. Mathematical simulation of the subsidence of Ravenna. Water Resources Research, 27(11), 2899-2918.

Gambolati, G., Teatini, P., 2015. Geomechanics of subsurface water withdrawal and injection. Water Resources Research, 51(6), 3922-3955.

Gambolati, G.,Teatini, P., Bau, D., Ferronato, M., 2000. Importance of poroelastic coupling in dynamically active aquifers of the Po river basin, Italy. Water Resources Research, 36(9), 24432459.

Hu, R.L., Yueb, Z.Q., Wang, L.C., Wang, S.J., 2004. Review on current status and challenging issues of land subsidence in China. Engineering Geology, 76, 65-77.

Ingerson, I. M.,1941. The hydrology of the of the Southern San Joaquin Valley, California, and its relation to important water supplies. Eos, Transactions, American Geophysical Union, 22 (1), 20-45.

Jacob, C.E., 1940. The flow of water in an elastic artesian aquifer. Eos, Transactions, American Geophysical Union, 21, 574-586.

Jafari, F., Javadi, S., Golmohammadi, G., Karimi, N., Mohammadi, K., 2016. Numerical simulation of groundwaterflow and aquifer-system compaction using simulation and InSAR technique: Saveh basin, Iran. Environmental Earth Sciences, 75(9), Article Number: UNSP 833.

Kang, D.H., Li, J., 2015. 3-D land subsidence simulation using the NDIS package for MODFLOW. Proc. IAHS, 372, 437-442.

Karahanoğlu, N., Doyuran, V., Akkaş, N., 1984. Finite element simulation of hot-water type geothermal reservoirs. Journal of Volcanology and Geothermal Research, 23, 357-382. 
Karahanoğlu

Kihm, J. H., Kim, J. M., Song, S.H., Lee, G. S., 2007. Three-dimensional numerical simulation of fully coupled groundwater flow and land deformation due to groundwater pumping in an unsaturated fluvial aquifer system. Journal of Hydrology, 335(1-2), 1-14.

Kim, J.M., 2004. Fully coupled poroelastic governing equations for groundwater flow and solid skeleton deformation in variably saturated true anisotropic porous geologic media. Geosciences Journal, 8(3), 291-300.

Kim, J.M., 2005. Three-dimensional numerical simulation of fully coupled groundwater flow and land deformation in unsaturated true anisotropic aquifers due to groundwater pumping. Water Resources Research, 141, 1, Article Number: W01003.

Kim, J.M., Parizek, R.R., 1999. Three-dimensional finite element modelling for consolidation due to groundwater withdrawal in a desaturating anisotropic aquifer system. International Journal for Numerical and Analytical Methods in Geomechanics, 23, 6, 549-571.

Kontogianni, V., Pytharouli, S., Stiros, S., 2007. Ground subsidence, Quaternary faults and vulnerability of utilities and transportation networks in Thessaly, Greece. Environmental Geology, 52(6), 1085-1095.

Kumarcı K., Ziaie, A., Kyioumarsi, A., 2008. Land subsidence modeling due to ground water drainage using "WTAQ" software. Proceedings of 10th WSEAS International Conference on Automatic Control, Modelling and Simulation, Istanbul, Turkey, May 27-30, 2008, Ed: Demiralp, M., Mikhael, W.B., Caballero, A.A., Abatzoglou, N., Tabrizi, M.N., Leandre, R., GarciaPlanas, M., Cjoras, R.S., 394-399.

Lei, H., Xu, T., Jin, G., 2015. TOUGH2 Biot-A simulator for coupled thermal-hydrodynamicmechanical processes in subsurface flow systems: Application to $\mathrm{CO} 2$ geological storage and geothermal development. Computers \& Geosciences, 77, 8-19.

Lewis, R.W., Roberts, P.J., Schrefler, B.A., 1989. Finite element modelling of two phase heat and fluid flow through deforming porous media. Transport in Porous Media, 4, 319-334.

Lewis, R.W., Karahanoğlu, N.,1981. Simulation of subsidence in geothermal reservoirs. Numerical Methods in Thermal Problems, 2, 326-335.

Lewis, R.W., Schreffler, B.A., 1978. A fully coupled consolidation model of the city of Venice. Water Resources Research, 14(2), 223-230.

Li, J., 2002. Modeling and sensitivity analysis of aquifer parameters for subsidence due to pumping-injecting water. Proc $9^{\text {th }}$ International Conference on Hydraulic Information Management MONTREAL, CANADA Hydraulic Information Management, Edited By Blain, W.R., Brebbia, C.A., 119-129.

Li, J., 2003. A nonlinear elastic solution for 1-D subsidence due to aquifer storage and recovery applications. Hydrogeology Journal, 11(6), 646658.

Li, J., Helm, D.C., 1997. Numerical formulation of dynamic behavior within saturated soil characterized by elasto-viscous behavior with an application to Las Vegas Valley. Computer Methods And Advances in Geomechanics, 2, 911-916.

Li, P., Wang, K., Li, X.G., Lu, D.T., 2014. Analytical solutions of a finite two-dimensional fluidsaturated poroelastic medium with compressible constituents. International Journal for Numerical and Analytical Methods in Geomechanics, 38(11), 1183-1196.

Lin, PL., Hsu, KC., Lin, CW., Hwung, HH., 2015. Modeling compaction of multi-layer-aquifer system due to groundwater withdrawal. Engineering Geology, 187, 143-155.

Lin Z., Huili G., Xiaojuan L., Rong W., Beibei C., Zhenxue D., Teatini, P.,2015. Land subsidence due to groundwater withdrawal in the northern Beijing plain, China. Engineering Geology, 193, 243-255.

Liu, C.H., Pan, Y.W., Liao, J.J., Huang, C.T., Ouyang, S., 2004. Characterization of land subsidence in the Choshui River alluvial fan, Taiwan. Environmental Geology, 45(8), 1154-1166. 
Loupasakis, C., Rozos, D., 2009. Finite-element simulation of land subsidence induced by water pumping in Kalochori village, Greece. Quarterly Journal of Engineering Geology and Hydrogeology, 42, 369-382.

Meinzer, O.E., 1928. Compresibility and elasticity of artesian aquifers. Economic Geology, 23, 263291.

Mitchell, J.K., 1962. Components of pore water pressure and their engineering significance. Clays and Minerals, Pergamon, N.Y., 162-184.

Nguyen, T.Q., Helm, D.C., 1998. Land subsidence due to ground-water withdrawal in Hanoi, Vietnam. Land Subsidence Case Studies and Current Research: Proceedings of the Dr. Joseph F. Poland Symposium on Land Subsidence, Association of Engineering Geologists, Special Publications, 8, 113-117.

Ortega-Guerrero, A., Cherry, J.A., Rudolph, D.L.,1993. Large-scale aquitard consolidation near Mexico-City, Ground Water, 31(5), 708718 .

Ortega-Guerrero, A, Rudolph, D.L., Cherry, J.A., 1999. Analysis of long-term land subsidence near Mexico City: Field investigations and predictive modeling. Water Resources Research, 35(11), 3327-3341.

Ortiz-Zamora, D., Ortega-Guerrero, A., 2010. Evolution of long-term land subsidence near Mexico City: Review, field investigations, and predictive simulations. Water Resources Research, 46, Article Number: W01513.

Pacheco-Martinez, J., Hernandez-Marin, M., Burbey, TJ., Gonzalez-Cervantes, N., Ortiz-Lozano, JA., Zermeno-De-Leon, M.E., Solis-Pinto, A., 2013. Land subsidence and ground failure associated to groundwater exploitation in the Aguascalientes Valley, Mexico. Engineering Geology, 164, 172186.

Paleologos, E.K., Mertikas, S.P., 2013. Evidence and implications of extensive groundwater overdraftinduced land subsidence in Greece. European Water, 43, 3-11.
Pei, S.P., Chen, C.G.,Jiao, J.J., 2000. Geological hazards related to groundwater exploitation - Land subsidence in Suzhou City, China. Proceedings of the International Symposium on Hydrogeology and the Environment, 546-552.

Poland, J.F., 1958. Land subsidence due to groundwater development. Journal of Irrigation and Drainage Division, American Society of Civil Engineering. 84(IR3), 11pp.

Poland J.F., 1960. Land subsidence in the San Joaquin Valley, California, and its effect on estimates of ground water resources. Comm. Sub Terranean Waters Publ. 52, 324-335.

Poland J.F., 1961. The coefficient of storage in a region of major subsidence caused by compaction of an aquifer system. US Geological Survey Professional paper 424-B, B52-B54.

Poland, J.F., 1984. Guidebook to studies of land subsidence due to groundwater withdrawal. USGS Report, Studies and Reports in hydrology 40, UNESCO, Paris, 305 p.

Poland J.F., Davis, G.H., 1956. Subsidence of the land surface in Tulare-Wasco (Delano) and Los Banos-Kenttleman City areas, San Joaquin Valley, California. Eos, Transactions, American Geophysical Union, 37(3), 287-296.

Poland, J.F., Garret, A.A., Sinnott, A., 1959. Geology, hydrology and chemical character of ground waters in the Torrance-Santa Monica area, California. US Geological Survey, Water Supply Paper, 1461, 142-146.

Poland J.F., Davis G.H., 1969. Land subsidence due to withdrawal of fluids, Reviews in Engineering Geology, Vol 2, edited by D.J. Varnes ve G. Kirsch, Geological Society America, Boulder Col. 187-269.

Pratt, W. E., 1927. Some questions on the cause of the subsidence of the surface in the Goose Creek field, Texas. American Association of Petroleum Geologists Bulletin, 11(8), 887-889.

Psimoulis, P., Ghilardi, M., Fouache, S., Stiros, S., 2007. Subsidence and evolution of the Thessaloniki plain, Greece, based on historical leveling and GPS data. Engineering Geology, 90, $1-2,55-70$. 
Karahanoğlu

Riley, F.S., 1998. Mechanics of aquifer systems - The scientific legacy of Joseph F. Poland, Land Subsidence Case Studies and Current Research: Proceedings of the Dr. Joseph F. Poland Symposium On Land Subsidence. Edited by Borchers, J.W., Association of Engineering Geologists, Special Publication, 8, 13-27.

Schmid, W., Hanson, R.T., Leake, S.A., Hughes, J.D., Niswonger, RG., 2014. Feedback of land subsidence on the movement and conjunctive use of water resources. Environmental Modelling \& Software, 62, 253-270.

Settari, A., Walters, D.A., Stright, D.H. Jr., Aziz, K., 2008. Numerical techniques used for predicting subsidence due to gas extraction in the North Adriatic Sea. Petroleum Science and Technology, 26, 10-11, 1205-1223.

Shearer, T.R., 1998. A numerical model to calculate land subsidence, applied at Hangu in China. Engineering Geology, 49(2), 85-93.

Shen, S.L., Xu, Y.S., 2011. Numerical evaluation of land subsidence induced by groundwater pumping in Shanghai. Canadian Geotechnical Journal, 48(9), 1378-1392.

Shen, S.L., Xu, Y.S., Hong, Z.S., 2006. Estimation of land subsidence based on groundwater flow model. Marine Georesources \& Geotechnology, 24(2), 149-167.

Shi, X.Q., Xue, Y.Q., Ye, S.J., Wu, J.C., Zhang, Y., Yu, J., 2007. Characterization of land subsidence induced by groundwater withdrawals in Su-XiChang area, China. Environmental Geology, 52(1), 27-40.

Sideri, D., Modis, K., 2014. Spatiotemporal estimation of land subsidence and ground water level decline in West Thessaly basin, Greece. Natural Hazards, Natural Hazards, 76(2), 939-954.

Stiros, S.C., 2001. Subsidence of the Thessaloniki (northern Greece) coastal plain, 1960-1999. Engineering Geology, 61(4), 243-256.

Taylor, D.W., 1948. Fundamentals of soil mechanics. John Wiley NY, 700 p.
Teatini, P., Ferronato, M., Gambolati, G., Bertoni, W., Gonella, M., 2005. A century of land subsidence in Ravenna, Italy, Environmental Geology. 47(6), 831-846.

Teatini, P., Ferronato, M., Gambolati, G.,Gonella, M., 2006. Groundwater pumping and land subsidence in the Emilia-Romagna coastland, Italy: Modeling the past occurrence and the future trend. Water Resources Research, 42(1), Article Number: W01406.

Terzaghi, K., Peck, R.B., 1948. Soil mechanics in Engineering Practice. John Wiley NY, 566 p.

Tsai, T.L., 2015. A coupled one-dimensional viscoelastic-plastic model for aquitard consolidation caused by hydraulic head variationsin aquifers. Hyrological Processes, 29, 4779-4793.

Üstün, A., Tuşat, E., Yalvaç, S., Özkan, I., Eren, Y., Özdemir, A., Bildirici, I.O., Üstüntaş, T., Kirtıloğlu, O.S., Mesutoğlu, M., Doğanalp, S., Canaslan, F., Abbak, R.A., Avşar, N.B., Şimşek, F.F., 2015. Land subsidence in Konya Closed Basin and its spatio-temporal detection by GPS and DInSAR. Environmental Earth Sciences, 73, 10, 6691-6703.

Wang, J., Wu, Y., Liu, X., Yang, T., Wang, H., Zhu, Y., 2016. Areal subsidence under pumping well-curtain interaction in subway foundation pit dewatering: conceptual model and numerical simulations. Environmental Earth Sciences, 75, 198.

Wang, S.J., Lee, C.H., Hsu, K.C., 2015. A technique for quantifying groundwater pumping and land subsidence using a nonlinear stochastic poroelastic model. Environmental Earth Sciences, 73(12), 8111-8124.

Wu, J.C., Shi, X.Q., Ye, S.J., Xue, Y.Q., Zhang, Y., Yu, J., 2009. Numerical simulation of land subsidence induced by groundwater overexploitation in $\mathrm{Su}-$ Xi-Chang area, China. Environmental Geology, 57, 1409-1421.

Xu, Y.S., Shen, S.L., Cai, Z.Y., Zhou, G.Y., 2008. The state of land subsidence and prediction approaches due to groundwater withdrawal in China. Natural Hazards, 45,123-135. 
Xu, Y.S., Ma, L., Shen, S. L., Sun, W.J., 2012. Evaluation of land subsidence by considering underground structures that penetrate the aquifers of Shanghai, China. Hydrogeology Journal, 20(8), 1623-1634.

Yang, Y., Song, X.F., Zheng, F.D., Liu, L.C., Qiao, X.J., 2015. Simulation of fully coupled finite element analysis of nonlinear hydraulic properties in land subsidence due to groundwater pumping. Environmental Earth Sciences, 73, 4191-4199.

Ye, S.L., Luo, Y.,Wu, J.C., Yan, X.X., Wang, H.M., Jiao, X., Teatini, P., 2016a. Three dimensional numerical modeling of land subsidence in Shanghai China. Hydrogeology Journal, 24(3), 695-709.

Ye, S., Xue, Y., Wu, J., Yan, X., Yu, J., 2016 b. Progression and mitigation of land subsidence in China. Hydrogeology Journal, 24(3), 685-693.

Ye, S., Xue, Y., Wu, J., Zhang, Y., Wei, Z., Li, Q., 2011. Regional land subsidence model embodying complex deformation. Proceedings of the Institution of Civil Engineers-Water Management, 164(10), 519-531.
Yeh, H.D., Lu, R.H., G.T. Yeh, 1996. Finite Element modeling for land displacement due to pumping. International Journal for Numerical and Analytial Methods in Geomechanics, 20, 79-99.

Yokoo, Y., Yamagata, K., Nagaoka, H., 1971a. Finite element method applied to Biot's consolidation theory. Soils and Foundations, 11(1), 29-46.

Yokoo, Y., Yamagata, K., Nagaoka, H., 1971b. Finite element analysis of consolidation following undrained deformation. Soils and Foundations, 11(4), 37-58.

Zang, Y., Wu, J.C., Xue,Y.Q., Wang, Z.C., 2017. Fully coupled three-dimensional nonlinear numerical simulation of pumping-induced land movement. Environmental Earth Sciences,76(16), 552.

Zhang, Y., Wu, J.,Xue, Y.Q., Wang, Z.C., Yao, Y.G.,Yan, X.X., Wang, H.M., 2015. Land subsidence and uplift due to long-term groundwater extraction and artificial recharge in Shanghai, China. Hydrogeology Journal, 23(8), 1851-1866.

Zienkiewicz, O.C., 1977. The finite element method. McGraw Hill, Berkshire, 787. 
